\title{
Los “Privilegios Rodados" originales del Archivo Ducal de Medinaceli: I. Alfonso VIII de Castilla (1158-1214)
}

\author{
The Originals 'Privilegios Rodados' From The Ducal Archive \\ of Medinaceli: \\ I. Alfonso VIII, King of Castile (1158-1214) \\ Antonio SÁnchez GonZÁlez \\ Universidad de Huelva \\ antonio.sanchez@dhis2.uhu.es
}

\begin{abstract}
RESUMEN
Este es el primer estudio parcial de una serie que estamos elaborando sobre la magnífica colección documental de Privilegios Rodados que custodia el Archivo de la Casa Ducal de Medinaceli, un buen número de ellos inéditos. De casi el centenar de pergaminos originales que constituye la colección, los seis primeros privilegios fueron emitidos por la cancillería del rey de Castilla Alfonso VIII entre los años 1175 y 1212. Este monarca fue el primero que intituló en Castilla privilegios con signo rodado y sello de plomo pendiente, sin duda el tipo documental más admirado desde la Edad Media por su solemnidad, belleza, elegancia, prestancia, jerarquía, vistosidad, fiabilidad y perdurabilidad. En estos ejemplares ya se vislumbran esas características y las formalidades de las que se rodearon estos documentos medievales para garantizar su autenticidad. El estudio va precedido de una introducción dedicada a los orígenes del privilegio rodado en las cancillerías hispanas.
\end{abstract}

Palabras clave: Alfonso VIII, rey de Castilla. Privilegio rodado. Archivo Ducal de Medinaceli. Cancillería real.

\begin{abstract}
This is the first partial study of a serie which we are elaborating about the magnificient documental collection of "Privilegios Rodados" which is watched over in the Ducal Archive of Medinaceli, a good number of them unpublished. From nearly a hundred of original rolls that constitute the collection, the first six privilegios were emited by the Royal Chancellery of the king of Castile, Alfonso VIII, between 1175 and 1212. This monarch was the first that entitled in Castile privilegios with signo rodado and hanging lead seal, undoubtedly the documental type more admired from the Middle Age for its solemnity, beauty, elegance, performance, hierarchy, brightness, reliability and durability. In these copies, it can be discerned that characteristics and the formalities of the ones that these medieval documents were surrounded in order to guarantee its authenticity. The study is preceded by an introduction dedicated to the origins of the privilegio rodado in the hispanic chancelleries.
\end{abstract}

Key words: Alfonso VIII, King of Castile. Privilegio Rodado. Ducal Archive of Medinaceli. Royal Chancellery.

Sumario: 1. Introducción: El origen del privilegio rodado. 2. Alfonso VIII y su cancillería (1158-1214). 3. Los privilegios rodados de Alfonso VIII en la Colección Medinaceli (1175-1211). 3.1. Mensajes textuales, o aspectos de contenido, de los privilegios alfonsinos. 3.2. Mensajes visuales, o aspectos formales y decorativos, de los pergaminos. 3.3. Los mensajes auditivos de los documentos. 4. Transcripciones y ambientación histórica de la documentación. 
El Archivo de la Fundación Casa Ducal de Medinaceli ${ }^{1}$ custodia en su actual sede del hospital Tavera de Toledo una extraordinaria colección de privilegios rodados originales, casi un centenar, que ya presentamos con anterioridad ${ }^{2}$. A partir de ahora, y a través de sucesivos estudios parciales, es nuestro propósito ir dando a conocer pormenorizadamente esta magnífica colección de los documentos más solemnes y de mayores formalidades de entre los que se expedían en la cancillería de los reyes de Castilla y León a lo largo de la Plena y Baja Edad Media.

Esta es la primera entrega de puesta en ejecución de ese propósito nuestro de ir desmenuzando, en su evolución, el estudio de este tipo documental a través de los 95 pergaminos originales que constituyen la que podíamos denominar «Colección Medinaceli $\rangle^{3}$, algunos de cuyos ejemplares sirvieron de paradigma para anteriores estudios globales, de distintos autores dedicados al privilegio rodado ${ }^{4}$, y otros que permanecen aún inéditos. En concreto, nosotros aquí tratamos inicialmente de los orígenes del privilegio real del que procede este tipo diplomático, para centrarnos en el argumento principal de este trabajo, que no es otro que el estudio de los privilegios rodados del rey castellano Alfonso VIII (1158-1214), un total de seis ejemplares, que son precisamente los que inician esta interesante colección ${ }^{5}$.

${ }^{1}$ Siglas: $\mathrm{ACT}=$ Archivo de la Catedral de Toledo. ADM = Archivo Ducal de Medinaceli. AHDE = Anuario de Historia del Derecho Español. AHN = Archivo Histórico Nacional.

2 Sánchez GonzÁlez, A.: "La colección de Privilegios Rodados originales del Archivo Ducal de Medinaceli (1175-1458)", Lope de Barrientos. Seminario de Cultura, 2 (2009), pp. 217-279.

${ }^{3}$ Cada vez que citemos algún número de documento de esta colección, remitimos al lector al catálogo-regesta incluido en el referido artículo de presentación.

${ }^{4}$ Me refiero principalmente a M ${ }^{a}$ Teresa Villar Romero que dedicó su tesis doctoral en 1964 a este tipo documental, de la que se publicó un extracto bajo el título de Privilegio y signo rodado (Madrid, 1966), citando trece privilegios rodados del Archivo Ducal de Medinaceli. A través de esa obra, también cita algún documento de la colección el trabajo de Ma de la Soterraña MarTín Postigo titulado "Notaría Mayor de los Privilegios y Escribanía Mayor de los Privilegios y confirmaciones en la cancillería real castellana", Actas de las I Jornadas de Metodología Aplicada de las Ciencias Históricas, vol. 5, 1975 (Paleografía y Archivística), pp. 241-254. Otros autores han citado y transcrito algunos de los privilegios rodados de la colección Medinaceli. Sin embargo, Julio GonzÁLez, que recopiló 962 documentos del monarca para el estudio de su clásica obra El reino de Castilla en la época de Alfonso VIII, 3 vols. (Madrid, 1960), no consultó ninguno de los pergaminos originales del ADM.

${ }^{5}$ No existe en la colección ninguna muestra original de privilegios rodados leoneses. Para el estudio del privilegio real, en general, en este reino son de interés los distintos trabajos publicados sobre la cancillería leonesa, como los de A. Millares CARLo: "La cancillería real en León y Castilla hasta fines del reinado de Fernando III", AHDE, 3 (1926), pp. 227-306; P. Rassow: "Die Urkunden Kaiser Alfons' VII, von Spanien. Eine paleographisch-diplomatische", Archiv für Urkundenforschung, X, III (1928), pp. 328-467, y XI, I (1930), pp. 66-137; B. ReILLY: "The Chancery of Alfons VII of León-Castilla: The period 1116-1135 reconsidered", Speculum LI (1976), pp. 243-261, y "The Chancery of Alfons VI of Léon-Castile (1065-1109)", en Santiago, Saint-Denis and Saint Peter. The reception ok the Roman Liturgy in Léon-Castile in 1080. New York, 1985, pp. 1-40; M. LuCAS Alvarez: Las cancillerías reales (1109-1230), tomo V de la colección El reino de León en la Alta Edad Media [reina Urraca, 33-85 Alfonso VII, 87-314 - Fernando II, 315-485 - y Alfonso IX, 487-597]. León, 1993; A. Gambra: Alfonso VI: Cancillería, Curia e Imperio. Estudio y colección diplomática. León, 1997, 2 vols.; I. RuIz AlBI: La reina Doña Urraca (1109-1126): cancillería y colección diplomática. León, 2003. 


\section{INTRODUCCIÓN: EL ORIGEN DEL PRIVILEGIO RODADO}

Desde siempre el Poder, para su consolidación, ha debido recompensar servicios prestados a quienes contribuyeron a su establecimiento. El privilegio podemos definirlo, en este contexto, como una concesión, permanente y hereditaria por lo común, que autorizaba al agraciado a disfrutar de la merced otorgada por el gobernante. En la Edad Media estas prerrogativas las concedía el rey a señores, villas, ciudades, iglesias, monasterios, órdenes militares, determinados gremios y otras instituciones, normalmente para agradecerles esos servicios prestados a la Corona. Los privilegios otorgados podían ser la concesión de señoríos, bienes y oficios, exención de determinados impuestos, permisos para establecer mercados, concesión de derechos de explotación de materias primas, monopolios, etc.

También desde siempre los soberanos ejercieron esta atribución regia plasmándola en testimonios escritos, normalmente rodeados - por la importancia del hecho jurídico documentado - de ciertas formalidades internas y de garantías externas. De ahí, por ejemplo, el uso generalizado del pergamino, como soporte material más resistente, o el empleo del signo real y el sello de plomo pendiente, como garantías de autenticidad.

Será precisamente el cambio de diseño del signo regio, normalmente de cuadrado o rectangular a circular, lo que dará lugar - junto con otros elementos propios que se le incorporan de inmediato- a un tipo de privilegio que será el más admirado a partir de los años centrales del siglo XII y hasta la época de los Reyes Católicos, en que desaparecerá. Así va a surgir, como tal, el conocido como privilegio rodado, de gran riqueza de fórmulas diplomáticas y apuntando, ya desde sus orígenes, una belleza que le va a caracterizar como el documento más solemne, vistoso y elegante de cuantos expedían entonces las cancillerías, una belleza y prestigio que llegará a su máximo esplendor en la Baja Edad Media. Como ya apuntábamos en el citado artículo de presentación de esta colección, "belleza, solemnidad, perpetuidad, fiabilidad y garantía jurídicas, perdurabilidad, firmeza, prestancia, vistosidad, jerarquía,..." son algunas de las características principales que imprimen carácter al privilegio rodado.

En efecto, mediado el siglo XII y reinando Alfonso VII "el Emperador" (11261157) tanto en Castilla como en León, se van a introducir ya algunas importantes modificaciones en la organización de los servicios de la Corona, entre ellos en la cancillería regia, que iban a tener una amplia repercusión en la documentación de la época ${ }^{7}$ y que pondrían las bases de las transformaciones que se avecinaban en los diplomas intitulados por sus sucesores, en uno y otro reino.

\footnotetext{
${ }^{6}$ Como pormenorizaremos en el siguiente artículo que estamos elaborando sobre el estudio de esta colección, el privilegio rodado será definido por Alfonso X como la "ley que es dada u otorgada del rey apartadamente a algún lugar o a algún hombre por le hacer bien e merced" (Partida $3^{\mathrm{a}}$, título XVIII, ley II). El propio Rey Sabio prescribirá y describirá formalmente este tipo diplomático en el Espéculo (ley 13) y en las propias Partidas (2a , título III, ley XVIII).

${ }^{7}$ Los privilegios de Alfonso VII comienzan con el monograma de Cristo, por regla general adornado con las letras alfa y omega, más la $\boldsymbol{S}$ (en la versión trinitaria), seguido de la invocación verbal "Sub Dei nomine", "In nomine Patris et Filii et Spiritu Sancti" o simplemente "In Dei nomine". En algunos documentos figura un preámbulo, caso de "Equitati et iusticie ut ei benefaciat unusquisque qui sibi fideliter et legitime servit huius rei gratia". Otras veces, sin preámbulo, sigue a las invocaciones la
} 


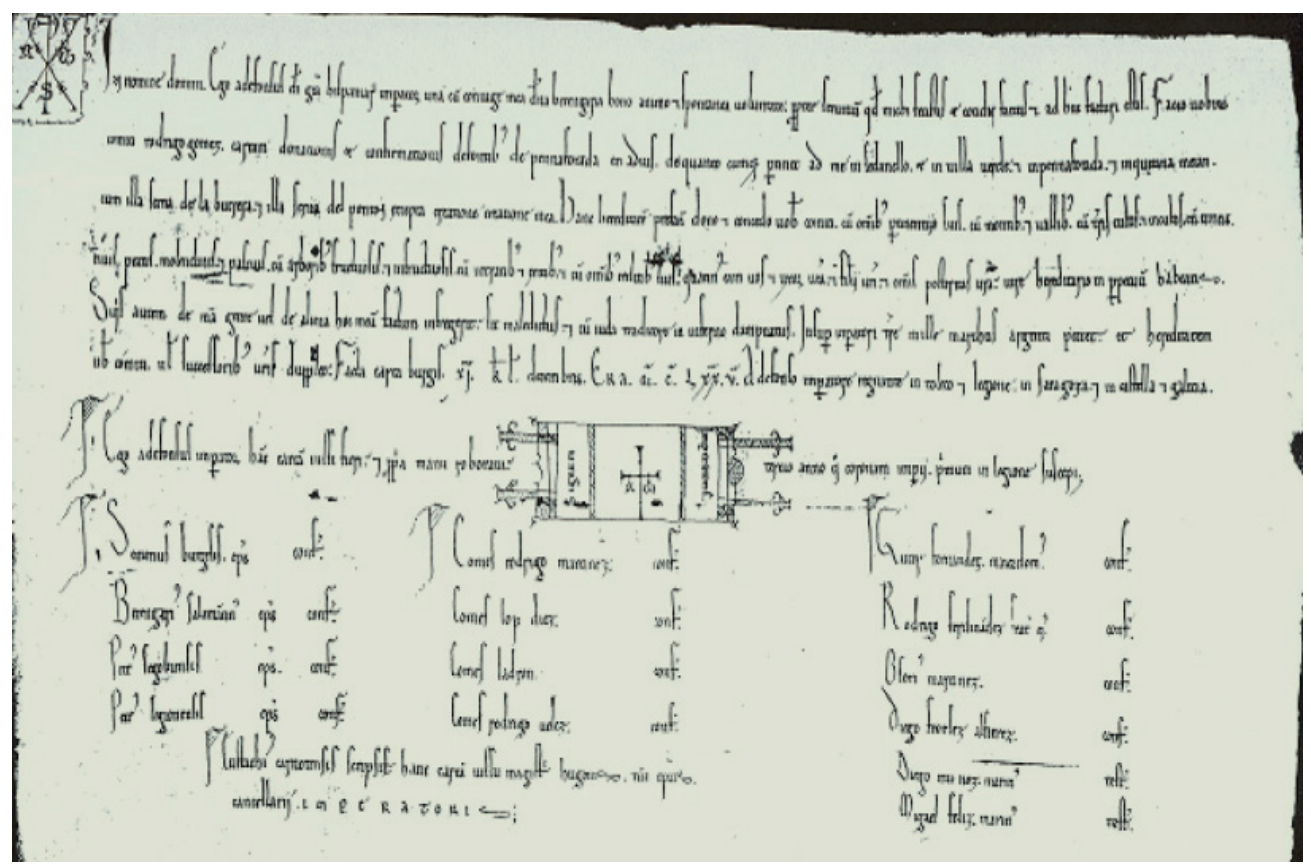

Privilegio de Alfonso VII de Castilla (1137). El signo regio — representado con la cruz latina, emblema del Imperio- es rectangular pues tiene dos bandas, una a cada lado del campo, donde se distribuye la leyenda "Signum Imperatoris"

dirección genérica: “...presentibus et futuris hominibus", junto a la notificación: "sit... manifestum...". Si la dirección es individualizada, figurará incluida en la parte dispositiva: "...facio cartam donationis vobis... et dono...", “...dono iure hereditario vobis domno...", etc. La exposición, con frecuencia, expresa la voluntad real de premiar servicios ("...propter servicium quod michi fecistis et facistis grato animo et voluntate spontanea...”). La intitulación recoge siempre el título imperial: “...ego Adefonsus, imperator Hispaniae, una cum uxore mea Berengaria...", "...ego Adefonsus, imperator Yspanie, una cum uxore mea ymperatrice Berengaria...". La data contiene todos los elementos, y se expresa conforme al cómputo de la era hispánica y la calendación romana: "Facta carta in ..., mense ..., era..." o "Facta karta apud urbem..., ...kalendas/idus/nonas..., era...". Algunas veces se añade la indicación del año del reinado: "anno... mei imperio", "anno...quod coronam in legione recepti”. La cláusula de corroboración incorpora la fórmula de dominio temporal: "Ego Adefonsus ymperator, hanc kartam quam iussi fieri, ymperante me una cum filiis meis Sanctio, Fredinando et Garsia, Toleto, Legione, Saragocia, Naiara, Castella, Gallecia, confirmo et manu mea roboro". Otras veces, irán separadas las fórmulas de enumeración de los reinos y la corroboración: "Adefonsus imperatore, imperante in Toletum, Legione, Cesaraugusta, Naiara, Castella, Galecia", y después "Ego Adefonsus imperator, hanc kartam quam iussi fieri... confirmo et manu mea roboro". Andando el tiempo, la fórmula que contiene la enumeración de los reinos de la Corona figurará a continuación del nombre del rey otorgante, en la intitulación del documento. Las relaciones de confirmantes se distribuyen en columnas como venía haciéndose en los privilegios de los reinados anteriores, y el signo real -con la cruz-, cuadrado o rectangular, aparece dibujado en el centro. Bajo el signo aparece, casi siempre, los nombres del canciller y del notario con las fórmulas antes indicadas. 
Una de esas modificaciones que se produce en los documentos afecta al privilegio hispano y consiste en la transformación del signo real, inscrito en una cartela cuadrangular, en signo rodado o circular, debido - más que nada - a la enorme influencia hegemónica de la cancillería papal, consecuencia del notable influjo espiritual que ejercía la curia romana sobre la cristiandad. En dicha cancillería se usaba la rota o rueda desde tiempos del papa León IX, concretamente a partir de 1048, aunque no alcanza su forma definitiva hasta el pontificado de Pascual II (1099-1118) ${ }^{8}$. Y por esa notable influencia de la curia papal sobre la sociedad medieval, muy pronto algunos eclesiásticos italianos — caso de los arzobispos de Benevento y Rávena-, empezaron a imitarla en sus documentos; casi a la vez, se introduce también en las cancillerías de los príncipes normandos-sicilianos ${ }^{9}$ y de reyes alemanes y franceses, aunque con uso esporádico, prueba inequívoca de adhesión y respeto a la figura del Papa. Algo después llegará también el empleo de la rota a la península Ibérica, concretamente a las cancillerías de León, Portugal y Castilla, que es donde va a perdurar el signo rodado a lo largo de toda la Edad Media ${ }^{10}$.

Sin embargo, el precedente inmediato de esa costumbre de validar de tal manera los documentos hispanos lo encontramos en la persona del arzobispo de Santiago, Diego Gelmírez (1100-1140), pues fue pionero en el uso del signo en forma circular, importando así la costumbre de la cancillería pontificia ${ }^{11}$. Alfonso VII le nombra canciller real en 1127, cargo que le confirma en 1133 y que le reafirma después mediante privilegio de 6 de junio de 1140, en el que le concede la propia cancillería y la capellanía real con derecho hereditario ${ }^{12}$. Y aunque al año siguiente ya había delegado el cargo en un familiar, el arzobispo compostelano tuvo tiempo más que suficiente para organizar la cancillería real transformándola según el modelo e influjo de la cancillería pontificia y de poner las bases del nuevo signum regis, que perdurará durante casi cuatrocientos años ${ }^{13}$.

Pero la transformación del signo real en signo rodado en el privilegio español, aunque a través de la mitra compostelana, no se llevó a efecto con el arzobispo Gelmírez sino, más adelante, en tiempos del arzobispo Martín Martínez (1156-1167), ya con los sucesores de Alfonso VII. La muerte de éste en 1157 provoca la división de Castilla y León en dos reinos independientes, y la necesidad obvia de diferenciar-

8 La rota consta de una cruz central, circundada de dos circunferencias concéntricas, a modo de anillo exterior, donde solían escribirse sentencias bíblicas o la divisa papal. La cancillería pontificia la utilizó, primero, para todo tipo de cartas apostólicas y, después, sólo para las más solemnes como las bulas mayores. En un primer momento la rota se sitúa bajo el texto y al lado izquierdo pero, con el gran papa Gregorio VII (1073-1085), se desplaza hacia el centro por la ausencia de la "Bene Valete". Esta estructura pasará a los privilegios rodados, donde la rueda ocupará el espacio central de validación con el rango de suscripción real.

9 Eitel, A.: "Rota und Rueda", Archiv für Urkundenforschung, 5 (1913-14), p. 299.

${ }^{10}$ Una buena síntesis sobre el origen del signo rodado en Ma.T. VILlar Romero, ob. cit., pp.13-15.

11 Antes de su proclamación en 1120 como arzobispo compostelano, ya había confirmado así un diploma, fechado el 31 de marzo de 1116, que inmediatamente fue imitado por las más cercanas diócesis gallegas. Otro suyo de 1122 en AHN, Clero, 512-9.

12 Villar Romero, Ma .T., ob. cit., p.14.

13 En cambio, la rota de los documentos episcopales dejó de usarse a partir del siglo XIII (PARDO Rodríguez, Ma .L.: "La 'rueda' hispana. Validación y simbología", Papsturkunde und Europäisches Urkundenwesen, Colonia-Viena, 1999, p. 242). 
se entre ellos ${ }^{14}$. Castilla queda para el primogénito, Sancho III (1157-1158), con el consiguiente derecho a usar el signo de la cruz heredado del emperador. León pasa a su otro hijo, Fernando II (1157-1188), quien a poco de acceder al trono, elige como emblema heráldico de poder y soberanía el parlante de un león pasante, inserto en un doble círculo con la leyenda "SIGNUM FERNANDI, LEGIONENSIS REGIS". Concretamente aparece este signo por primera en un privilegio fechado el 18 de octubre de $1158^{15}$. Es el inicio de la rueda y, por extensión, del privilegio rodado.

Por su parte, en Castilla, su más tardía aparición se debe a la repentina muerte de Sancho III ese mismo año -efímero monarca del que no se conserva ningún privilegio original con signo rodado ${ }^{16}$ pues sus documentos más solemnes los signó de forma similar a la última etapa de Alfonso VII-. Unos años después, ya durante la minoría de Alfonso VIII, hijo y sucesor de Sancho III, la cancillería real castellana emite un privilegio con el signum regis circular, efigiado con la cruz del reino, que está fechado el 15 de julio de 1165 (ése es, al menos, el primer original que se conserva $)^{17}$. Sirviéndose, pues, del modelo leonés, el canciller castellano - al que, de inmediato, conoceremos - coloca la rueda en el centro de la parte reservada a la validación de los privilegios, flanqueada por los confirmantes, y la envuelve con un anillo donde inscribe la leyenda "SIGNUM REGIS ADEFONSI". Justificada imitación si tenemos en cuenta la tutela que ejerció el rey leonés sobre su sobrino, el castellano, aún niño de 10 años, y todo el reino castellano.

También en Portugal el canciller magister Albertus (1142-1169) ya había adoptado la rota en su última etapa al frente de la cancillería del primer rey luso Alfonso $\mathrm{I}^{18}$.

${ }^{14}$ En un principio el signum regis se identificaba con la persona del monarca y no con el territorio (por ejemplo, Alfonso VI y Alfonso VII usan un monograma a base de yuxtaponer la inicial y las consonantes del nombre "Adefonsus"). Pero a partir del siglo XII el signo regio cambia de significado y pasa a convertirse en signo del reino: el signum imperii. Esta transformación está íntimamente ligada a la proclamación, en 1135, de Alfonso VII como emperador en la catedral de León. Sobre el signo real tiene interés el trabajo de J.A. Martín Fuertes, "El Signum regis en el reino de León (1157-1230): notas sobre su simbolismo (I)", Argutorio: revista de la Asociación cultural "Monte Irago", 9 (2002), pp. 1519; - "El Signum regis en el reino de León (1157-1230): notas sobre su simbolismo (II)", en Ibidem, 10 (2003), pp. 12-13 [Antes publicado en Graphische Symbole in Urkunden. Beiträge zur diplomatischen Semiotik, Sigmaringen, 1996 (Historische Hilfswissenschaften 3, obra coordinada por Peter Rück, pp. 463-478. Y aún antes: "El signum regis en el reino de León (1157-1230). Notas sobre su simbolismo", Graphische Symbol in die Mittelarliche (Minden, 1983)].

15 AHN, Clero, 1240-4. Reproducido, entre otros, por Ma. Teresa ViLlar Romero, ob. cit., p.17.

16 Pues el único que se ha conservado con esas características, datado el año 1153 (A.H.N., Clero -Sahagún-, carp. 898, núm. 17), parece una copia imitativa muy posterior, en la que efectivamente aparece un signo regio rodado con la leyenda «SIGNUM REGIS SANCII», copia realizada algunas décadas después de esa fecha. Según J. GonzÁLez, este signo rodado «es análogo a los de Alfonso VIII de hacia 1170» (ob. cit., II, p. 24) pero, para J.A. MARTín FuerTes, el peculiar crismón y los rasgos gráficos del privilegio permitirían retrasar algo más la fecha de su ejecución (ob. cit. I, p. 17). Este privilegio fue publicado por A. FloRiano CuMBreÑo (Curso General de Paleografía y Diplomática españolas. Oviedo, 1946 - pp. 27-28 y lám. XIV). Vid. también la crítica de EITEL (ob. cit., p. 316).

17 AHN, Ordenes Militares - Uclés, 356-1. Vid. J. GonzÁlez, ob. cit., II, pp.120-121 (doc. 70). Un mes antes el monarca expidió otro privilegio, de similares características, que se conserva en copia en el mismo AHN, (Registro de escrituras de Calatrava, I fol. 13).

18 J.A. Martín Fuertes: Ob. cit., I, pp. 16-17. En el recién creado vecino reino portugués, aunque existen diversos prototipos de privilegios —algunos de un gran efecto decorativo-, el tipo básico de este período estaba formado por una o varias circunferencias concéntricas con las leyendas correspondientes 
Es evidente que, en el momento en que la rota episcopal pasa a las cancillerías reales, la carga simbólica de la rueda va a representar aspectos mucho más tangibles y terrenales que espirituales o religiosos. Pero, en definitiva, de lo que se trataba tanto en uno como en otro caso- era de plasmar la autoridad del emisor. No en vano, la manifestación simbólica de Poder, tal como se entendía entonces, tiene su origen en la instancia divina e intenta mostrar su legitimación a través de un signo que representa ese poder territorial y jurisdiccional. Con el tiempo la rueda ira adquiriendo su configuración definitiva, una disposición textual y ornamental específica y, sobre todo, una función simbólica que irá variando y matizándose a raíz de coyunturas políticas, como iremos comprobando en los sucesivos estudios que estamos preparando de esta colección diplomática.

En cualquier caso, la introducción del privilegio rodado en las cancillerías hispanas ${ }^{19}$ no significó la desaparición inmediata del privilegio real signado de otra manera, pues ambos tipos conviven. Es más, de hecho la cancillería de Alfonso VIII seguirá produciendo privilegios signados sin la rueda, en clara continuidad de la tradición anterior que se remonta a los antiguos privilegios astur-leoneses, si bien es cierto que la producción de este tipo documental disminuyó considerablemente desde la aparición del privilegio rodado (su producción no llegó a la veintena a lo largo del reinado), al contrario de lo que ocurre en la cancillería leonesa de Fernando II y Alfonso IX ${ }^{20}$.

\section{ALFONSO VIII Y SU CANCILLERÍA (1158-1214)}

Hijo único de Sancho III de Castilla y de Blanca de Navarra, Alfonso VIII había nacido en Soria, en 1155, y fue rey de Castilla desde el 31 de agosto de 1158 (cuando sólo tenía tres años de edad), hasta su muerte en $1214^{21}$.

Durante su larga minoría de edad, hubo un período de desgobierno y de vaivenes políticos, entre otras razones por la rivalidad entre sus tutores, que fue aprovechado por algunos monarcas vecinos - como Sancho VI de Navarra e incluso su propio tío, Fernando II de León- para apoderarse de amplios territorios castellanos. Por eso, cuando en 1169 alcanzaba la mayoría de edad a los 14 años, y una vez que es proclamado rey de Castilla en las Cortes de Burgos, el primer objetivo de Alfonso VIII como monarca fue recuperar aquellos territorios perdidos. Para ello se alía con el rey aragonés Alfonso II el Casto, logrando arrebatar en 1173 a Sancho VI las comarcas que éste había ocupado e incorporado al reino navarro poco antes.

y con el campo interior dividido por una cruz de brazos perpendiculares o por la cruz de los templarios (Vid. P. Avelino de Jesús DA CostA, "La Chancellerie royale portugaise jusqu'au milieu du XIII" siècle", Revista Portuguesa de Historia XV (Coimbra, 1975), pp. 143-169, en especial la p. 165).

19 Según M $M^{\mathrm{a}}$ Teresa Villar (ob. cit., pp. 15 y 41) incluso el conde de Cabra usó en 1176 el privilegio rodado (AHN, Ibidem, 356-21).

20 La cancillería de Alfonso IX de León reduce bastante la producción de privilegios rodados, mientras que sí emite con mayor profusión otros privilegios con signo rectangular, e incluso sin signo (cfr. J. GonzÁlez, Alfonso IX, 2. vols. (Madrid, 1944), I, pp. 491-502; y M. Lucas Álvarez, ob. cit., pp. 564-565.

${ }^{21}$ La obra más completa de este largo reinado es el ya citado libro de J. GonZÁLEZ El reino de Castilla en la época de Alfonso VIII. 
Presionado por los ataques almohades, en 1174 cedió a la orden de Calatrava la fortaleza de Zorita de los Canes, con todo su alfoz, y a los caballeros de Santiago la villa-fortaleza de Uclés, que fue desde entonces la casa principal de esta orden militar. Tomando esta plaza como base de operaciones, Alfonso VIII inicia entonces una ofensiva contra los musulmanes que culmina con la toma de Cuenca (1177). Después firma con su aliado, el rey aragonés, el tratado de Cazola (1179), por el que ambos soberanos se reparten - sobre el papel, ya que no tuvo resultados efectivos-, los territorios del reino navarro, y fijan las zonas de conquista de Al-Andalus que cada monarca podía emprender. Por dicho tratado, el reino de Murcia - cuya conquista correspondía a Aragón - pasaba a Castilla y, a cambio, Alfonso II de Aragón se vio libre del vasallaje que debía al monarca castellano.

Tras fundar Plasencia (1186), y con intención de unificar a la nobleza castellana, Alfonso VIII relanza la Reconquista, recupera la parte de La Rioja que estaba en manos navarras y la reintegra a Castilla. Establece una alianza con los demás reinos peninsulares cristianos - Portugal, León, Navarra y Aragón - para proseguir la conquista de las tierras ocupadas por los almohades. En 1188 firma un pacto de buena voluntad con su primo Alfonso IX de León (1188-1230), que acababa por entonces de suceder a su padre Fernando II, pacto que Alfonso VIII romperá pronto para, aprovechando la debilidad del nuevo monarca en su propio reino, invadir León y anexionarse varias poblaciones leonesas, hecho que inició un período de hostilidades entre ambos reinos vecinos que finalizaría con la firma del tratado de Tordehumos (1194), en el que el monarca castellano pactaba devolver los territorios recién conquistados y el leonés se comprometía a contraer matrimonio con una hija de Alfonso VIII, Berenguela; se pactaba además que el reino de León pasaría a ser anexionado por Castilla en el caso de que Alfonso IX muriese sin descendencia.

Este acuerdo permite al monarca castellano romper la tregua que mantenía con los almohades desde 1190, e inicia incursiones en Al-Andalus llegando hasta Sevilla. El califa almohade Yusuf II, que se encontraba en el norte de África, cruza el estrecho de Gibraltar y desembarca en Tarifa al frente de un poderoso ejército con el que se dirige hacia tierras castellanas. Alfonso VIII, enterado de la noticia, reúne a su ejército en Toledo y, aunque consiguió el apoyo de los reyes de León, Aragón y Navarra para hacer frente a la amenaza almohade, sin esperar a la llegada de estas tropas aliadas, entra en combate contra los almohades y sufre una severa derrota en Alarcos (1195), que supuso una importante pérdida de territorio y la fijación de la nueva frontera entre Castilla y Al-Andalus en los montes de Toledo. Los almohades llegaron entonces a invadir el valle del Tajo, e incluso a asediar Toledo, Madrid y Guadalajara en el verano de 1197. Castilla se encontraba así en una situación comprometida, con posibilidad de perder Toledo y todo el valle del Tajo, por lo que Alfonso VIII solicitó al papa Inocencio III la predicación de una Cruzada, a la que no sólo respondieron sus súbditos castellanos sino también los aragoneses, con su rey Pedro II a la cabeza, los navarros dirigidos por Sancho VII el Fuerte y las órdenes militares, aparte los cruzados ultramontanos - llamados así por su procedencia de más allá de los Pirineos-. Con todas estas fuerzas cristianas aunadas y, tras la recuperación de varios enclaves del valle del Guadiana (Calatrava, Alarcos o Benavente, entre otros), Alfonso VIII conseguía el 16 de julio de 1212 una sonora victoria sobre el sultán almohade Al- 
Nasir (el Miramamolín, como le llamaban los cristianos), en la célebre batalla de las Navas de Tolosa, que vino a significar el fin del imperio almohade en la península Ibérica y la consolidación de la frontera castellana en Sierra Morena, que hizo saltar el cerrojo de la puerta de Andalucía facilitando así las grandes conquistas castellanas del siglo XIII' ${ }^{22}$.

No mucho tiempo después, en la madrugada del 6 de octubre de 1214, fallecía el rey castellano y era sepultado en el monasterio burgalés de las Huelgas, en adelante panteón de los reyes de Castilla, que él mismo había fundado.

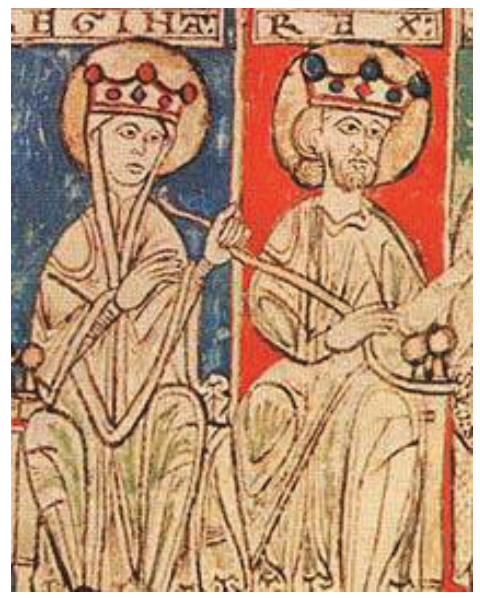

Alfonso VIII fue el fundador del primer estudio general español, el studium generale de Palencia (germen de la universidad) ${ }^{23}$. Además, su corte fue un importante instrumento cultural, que acogería trovadores y sabios, especialmente por la influencia de su esposa gascona, Leonor de Plantagenet (hija de Enrique II de Inglaterra y de Leonor de Aquitania, y - como tal- hermana de Ricardo Corazón de León). A los 26 días de la muerte del monarca fallecía también la reina, siendo sepultada a su lado en Las Huelgas. Con estas exequias, en los primeros días de noviembre de 1214 se cerraba la época de Alfonso VIII, el más largo reinado castellano, y se abría -de nuevo- un período de inestabilidad bajo el reinado nominal de un rey niño, Enrique I.

Sus biógrafos destacan de la personalidad de Alfonso VIII su carácter reflexivo, decidido y maduro - fruto, en parte, de su pronta orfandad y de haberse criado sin ningún calor familiar ${ }^{24}-\mathrm{y}$ lo definen como un gran rey por su decisión en asentar

${ }^{22}$ Sobre esta celebérrima batalla que dio tanto prestigio a Alfonso VIII, vid. SÁnchez González, A. capítulo 2 ("Edad Media") del libro Ruta por las batallas históricas en Andalucía: entre la épica y la violencia, Sevilla, 2008, pp. 60-85.

23 Esta Universidad funcionaba, al menos, desde 1178 (Vid. A. García y García, "El studium bononiense y la Península Ibérica", Iglesia, Sociedad y Derecho, Salamanca, 1985, pp. 45-64). Esto explicará la notable presencia de maestros palentinos como calígrafos de la documentación real durante el último cuarto del siglo XII (pp. 48-49).

${ }^{24}$ Su madre murió cuando él tenía 9 meses, su padre antes de que cumpliera los tres años, no tuvo hermanos ni hermanas, y con sus tíos y primos apenas mantuvo contactos. Su educación fue confiada durante la minoría de edad a cuatro tutores: Gutierre Fernández de Castro (menos de seis meses), 
unas amplias fronteras para su territorio, que hicieron de Castilla el reino cristiano principal y hegemónico de la península Ibérica, por la prudencia y clarividencia con que supo resistir y triunfar sobre el poderoso imperio almohade, o por la prosperidad económica castellana que se alcanzó durante su reinado. Otros rasgos del monarca fueron una profunda fe cristiana, la defensa de la justicia, su valor fuera de duda (probado en combate), su gusto por las artes, la sencillez y sobriedad de sus costumbres, una generosidad extrema y una modélica vida familiar, pese a alguna leyenda que se le atribuye sobre los amores con una judía toledana, con argumentos más literarios que históricos ${ }^{25}$.

$* * * * *$

Aunque falta aún un estudio profundo de la cancillería de Alfonso VIII ${ }^{26}$, algunos ya se han aproximado a ella ${ }^{27}$ basándose, precisamente, en la consulta de la colección diplomática del reinado recopilada por el propio J. González, un total de 962 documentos del monarca castellano - de ellos, unos 375 originales-, con abundante presencia de privilegios rodados ${ }^{28}$.

No se puede afirmar, sino todo lo contrario, que la cancillería regia castellana en el reinado de Alfonso VIII estuviera ya plenamente organizada y estructurada, como ocurrirá en tiempos posteriores. Esta oficina palatina tenía entonces aún una estructura bastante elemental, aunque suficiente para cubrir las funciones que le eran propias de redacción, ejecución escrita y validación de los documentos intitulados por los soberanos castellanos. Su composición, en consonancia, era muy sencilla -el canciller, los notarios y los escribanos o ejecutores materiales de la puesta por escrito-, aunque no siempre había personal suficiente para este reparto de funciones, llegando

García García de Aza (un año y medio), Manrique Pérez de Lara (cuatro años) y Nuño Pérez de Lara (cinco años). Pero el rey leonés, su tío Fernando II, siempre quiso ejercer su tutela sobre el menor para inmiscuirse en los asuntos del reino castellano.

${ }^{25}$ Aparte del tomo I de la colosal obra, ya reiterada, de Julio González sobre este monarca, es útil la biografía de G. Martínez Díez Alfonso VIII, rey de Castilla y Toledo (Burgos, 1995).

${ }^{26}$ Como los realizados, por ejemplo, por Andrés Gambra e Irene Ruzz Albi para las cancillerías de Alfonso VI y la reina Urraca, respectivamente, ambos estudios ya citados.

27 Ostos SAlcedo, Pilar: "La cancillería de Alfonso VIII, rey de Castilla (1158-1214). Una aproximación", Boletín Millares Carlo, $\mathrm{n}^{\circ} 13$ (1994), Actas del congreso "Agustín Millares Carlo: maestro de medievalistas", pp. 101-135 [en línea: http://dialnet.unirioja.es/servlet/articulo?codigo=1465786 (consulta: 21-09-2011)]. Preferentemente de este artículo hemos extraído la síntesis, que hacemos seguidamente, de la evolución de la cancillería Alfonsina. También nos ha sido muy útil las obras de J. A. García Luján Privilegios reales de la catedral de Toledo (1086-1462), Toledo, 1982 -en cuya colección diplomática se incluyen 22 privilegios rodados de Alfonso VIII (tomo II, pp. 67-113)-, de J. M. Fernández Catón Colección documental del Archivo de la catedral de León (775-1230), vols. V (1109-1187) y VI (1188-1230), León, 1990 y 1991, y de J. A. FernÁNDEz Flórez Colección diplomática del monasterio de Sahagún (857-1230), vols. IV (1110-1199) y V (1200-1300), León, 1991 y 1994. Además hemos consultado el artículo del profesor A. Millares CARLO "La cancillería real en León y Castilla hasta fines del reinado de Fernando III", pp. 227-306 (concretamente dedicadas a la cancillería de Alfonso VIII las pp. 269-281); y, comparativamente respecto al reino leonés, la obra ya citada de Lucas Álvarez, M.: "Las cancillerías reales (1109-1230)", en particular las de los monarcas Fernando II (pp. 315-485) y Alfonso IX (pp. 487-597).

${ }^{28}$ GonZÁlez, J.: Ob. cit., tomos II y III, dedicados a presentar la colección diplomática. 
incluso el notario en algunas ocasiones a tener que ser el autor material del escrito, como comprobaremos de inmediato. De hecho, podemos garantizar que la plantilla cancilleresca de Alfonso VIII fue bastante reducida, y mucho más durante los primeros años convulsos del reinado cuando aún era menor de edad, como nos recuerda $\mathrm{P}$. Ostos ${ }^{29}$; ello tiene más valor pues precisamente fue en esos años de la década de los sesenta del siglo XII cuando se produjeron los cambios más sobresalientes de la cancillería castellana, la mayoría de ellos con incidencia directa en la aparición del privilegio rodado como nuevo tipo documental. Por demás, las personas que prestaron sus servicios en esta cancillería, normalmente clérigos $^{30}$, demostraron tener un nivel de preparación más que aceptable, muchas de ellas formadas en el studium generale palentino o en la Colegiata de Santa María de Valladolid ${ }^{31}$.

Durante los largos años de reinado del monarca castellano (1158-1214) la cancillería real iría paulatinamente perfeccionándose, aumentando su plantilla, y adquiriendo una jerarquía de funciones. En ese tiempo se sucedieron cuatro cancilleres al frente de esta oficina de la corte, que marcan las sucesivas fases que se pueden establecer en la evolución de la cancillería alfonsina:

\section{1) RAIMUNDUS (1161-1178)}

Aunque se tiene constancia de que en 1160 era canciller del reino de Castilla el arzobispo de Toledo Juan - y actuaba como notario real el suyo, de nombre Bruno ${ }^{32}$ - a partir del año siguiente ya se encuentra actuando en la cancillería, al principio como notario y, desde 1164 hasta marzo de 1178, como canciller, el clérigo Raimundo (exceptuando esporádicas ausencias suyas ${ }^{33}$ y un período más largo, coincidente con el final de la minoría del rey, el bienio 1168-69, también de ausencia en el que, en su lugar, ejerció como tal el notario Martinus Ferdinandi). De Raimundo, lamentablemente, apenas se conocen datos biográficos pero, es evidente, que realizó una labor encomiable al frente de la cancillería castellana, largo tiempo prácticamente en solitario o con muy escasa ayuda ajena. Pues, al principio, siendo ya canciller, no sólo se ocupó de la redacción y validación de muchos documentos reales sino incluso fue

${ }^{29}$ P. Ostos SAlcedo: Ob. cit., p. 104.

30 Según J. GonzÁlez (Fernando II, pp. 164-165), entre el personal de la cancillería, el canciller suele ser obispo, arcediano o maestrescuela; el notario, un canónigo o maestro; y el escriba, era un clérigo simple.

31 Vid. P. Ostos Salcedo: Ob. cit., pp. 114-115, citando los trabajos de: Mañueco A. y J. Zurita, Documentos de la Iglesia Colegial de Santa María la Mayor de Valladolid, 3 vols. (Valladolid, 19171920); Rucquor, A., "Fundación y evolución de la abadía de Santa María la Mayor de Valladolid", Pasado histórico de Castilla y León, I (Burgos, 1983), pp. 429-440; Aвалo Martín, T., Documentos de la catedral de Palencia (1035-1247), Palencia, 1987; y GARCÍA de CorTÁzAR, M.A., "Cultura en el reinado de Alfonso VIII de Castilla: signos de un cambio de mentalidades y sensibilidades", en Alfonso VIII y su época, II (Aguilar de Campoo, 1992), pp. 167-194.

${ }^{32}$ En un documento fechado el 11 de julio de ese año nos encontramos con la siguiente fórmula: Hanc cartam scripsit Brunetus, notarius Toletani archiepiscopi, cancellari regis Ildefonsi (J. GonzÁLEZ, El reino de Castilla en la época de Alfonso VIII, II, p. 95, doc. 52).

${ }_{33}$ Por ejemplo, en octubre de 1165 Raimundo no estaba el Ávila, donde se expidió un documento por parte de Hugo, que se titula canciller (GonZÁlez, J.: Ob. cit., II, docs. 76 y 77, pp. 130-133). 
su autor material, sin que nadie más interviniera en el proceso de expedición ${ }^{34}$. Es más, se sabe que - en ocasiones - también compuso él mismo la rueda, hecho que explicita el privilegio ${ }^{35}$.

Se trata, sin duda, de la principal figura que tuvo la cancillería a lo largo de todo el reinado de Alfonso VIII pues, no en vano, introdujo importantísimas innovaciones en la documentación regia castellana: el signo rodado en los privilegios como principal elemento validativo, el sello de plomo pendiente, para los documentos más solemnes (como el propio privilegio rodado, pero también la carta plomada), y la creación de un nuevo documento para expedir las órdenes regias, el mandato, más breve y carente de formalidades.

Estos fueron los notarios que tuvo el canciller Raimundo durante su actividad profesional: Paulus (1164), Petrus Sancte Crucis, abad de Valladolid — también llamado Petrus de la Cruce y, sin duda, su principal oficial- (1167-1170), Petrus (11701176), Petrus Guterriz (1171), Elías (1173), Veremudus (1173-1174), y el "magister" Iohannis Roderici (1176-1178).

\section{2a) Petrus de CARDOna (1178-1182)}

Tras un breve período de dos meses (abril-mayo de 1178), en el que actuó como canciller de Castilla el arcediano de Toledo Guillelmus de Hastaforte — con el citado Pedro de la Cruz como notario-, el 23 de julio de ese año iniciaba su actividad al frente de la cancillería regia Pedro de Cardona, de origen catalán y posible hijo consanguíneo del monarca. Y, aunque su mandato apenas sobrepasó los cuatro años pues acabó en agosto de 1182, con su muerte, en tan corto período hubo una relativa alta producción cancilleresca. El año antes había sido electo arzobispo de Toledo, pero no llegó a ocupar esa mitra de manera efectiva como consecuencia de su fallecimiento. Dicho nombramiento del cabildo toledano (ratificado luego por el papa Alejandro III) le había obligado a estar apartado de la cancillería entre 1181-82 para ocuparse en Roma de su carrera eclesiástica, pese a lo cual, aquélla fija entonces mejor su funcionamiento y se regulariza en determinados aspectos, como el de otorgar mayor importancia a los notarios en tanto que verdaderos encargados de esta oficina palatina.

En este breve período, Pedro de Cardona tuvo tres notarios a sus órdenes: el ya conocido Petrus de la Cruce (1178) de la etapa anterior y, coetáneamente, los "magister" 36 Iohannes (1178-1181) y Geraldus (1178-1182). Este último, que probablemente procedía de la diócesis de Burgos, fue canónigo de Cuenca y arcediano además de posible maestrescuela - de Palencia, además de la principal figura activa de la cancillería durante este período pues, en ausencia del titular, recayó sobre él la

34 Basta con visualizar la serie de documentos originales de este canciller para comprobar tal extremo.

35 Vid. documentos 88, 228, 229 y 258 de la colección diplomática de J. GonZÁlez, ob. cit., II, pp. 50-52; 381-384 y $425-427$.

36 Parece que el término magister designaba, dentro de la cancillería, a juristas con la misión principal de encargarse de la redacción de los documentos y de la validación, antes que de la puesta por escrito. 
responsabilidad de dirigirla en estos años (correspondiéndole, por ejemplo, poner por escrito el tratado de paz suscrito en Medina de Ríoseco por Alfonso VIII con el rey de León de 28 de marzo de $1181^{37}$ ), e incluso prolongó su actividad notarial durante la fase siguiente.

Durante esta fase la reina, por su parte, tuvo como canciller personal a Egidio, como se desprende de un privilegio rodado que se conserva, otorgado por doña Leonor en 1179 , en el que concedía una serie de prebendas a la catedral de Toledo ${ }^{38}$.

\section{$\left.3^{\mathrm{a}}\right)$ GUTERRIUS RODERICI (1182-1192)}

El tercero de los cancilleres de Alfonso VIII ejerció esta función palatina durante casi una década, tiempo del que se conservan un cuarto de millar de documentos intitulados por el soberano. Gutierre Rodríguez, hijo del mayordomo del rey Rodrigo Gutiérrez ${ }^{39}$, contó con dos notarios para el desempeño de las tareas cancillerescas: el ya conocido magister Geraldus (1182-1184) y un "habilísimo calígrafo y excelso estilista" — según Millares ${ }^{40}$ - el magister Mica ${ }^{41}$, prácticamente durante todo el período (1183-1192) $)^{42}$, e incluso después. Aparte otros aspectos concretos que comentaremos posteriormente - sobre el crismón, la rueda, etc.- - con este notario se adquiere la costumbre en el privilegio rodado de resaltar el nombre del monarca y la expresión de derecho divino en letras mayúsculas; y también la de incorporar una triple data, añadida a las tópica y crónica, con los hechos más sobresalientes del momento (data histórica). Y eso que, de nuevo, parece que la cancillería real en estos años sólo contó con su servicio efectivo para confeccionar los documentos reales.

\section{$4^{\mathrm{a}}$ ) DIDACUS GARSIE (1192-1214)}

Durante los últimos veintidós años de reinado de Alfonso VIII (e incluso algunos más del inicio de su sucesor Enrique I), el hombre que estuvo a cargo de la cancillería castellana fue Diego García, natural de Campos y autor de una obra ascética-moral titulada Planeta (1218). E incluso, aunque el 1 de julio de 1206 el monarca vinculara

37 “...per mandatum amborum predictorum regum...”, según reza el documento (J. GonZÁLEZ: El reino de Castilla..., II, no. 362, pp. 614-623).

38 ACT, sign. A.2. G.1.5., perg $^{\circ}$ 260/350 (1179, abril, 30. Toledo). Privilegio rodado de la reina con sello de cera pendiente. Publicado por J.A. GARcía Luján: Privilegios reales de la catedral de Toledo (1086-1462), II, pp. 301-302 (doc. 119). En la línea de cancillería, que cierra el documento, figura: "Egidius, cancellarius regine, hoc scribere fecit".

39 Vid. A. Millares, “La cancillería real...”, pp. 274-275 y nota 303 (citando a J. LóPEZ AGURLETA: Vida del venerable fundador de la orden de Santiago y de las primeras casas de redempción de cautivos. Continuación de la apología por el hábito canónigo del patriarcha Santo Domingo en la misma orden, Madrid, 1731, p. 197).

40 A. Millares, ob. cit., p. 275.

41 Mica era de origen burgalés y fue bienhechor de la catedral de Burgos, según L. SERRANO (El obispado de Burgos y Castilla primitiva, II, Madrid, 1935, pp. 163-164).

42 Fue el principal artífice, en esta primera fase de su trabajo en la cancillería, del documento 4 de nuestra colección. 
la cancillería castellana a la mitra toledana (como la de León lo estaba desde tiempo atrás a la compostelana), esta concesión del rey —que se reservaba el nombramiento de notarios y demás oficiales cancillerescos - sólo podía ser efectiva hasta tanto que Diego García dejara el cargo ${ }^{43}$. De ahí que la figura del arzobispo de Toledo como canciller de Castilla no dejara de ser, al menos durante aquellos años, una merced teórica o nominal más que efectiva, que no se alteraría hasta mucho más tarde cuando, en 1230, el rey Fernando III el Santo se la confirme al arzobispo Rodrigo Jiménez de Rada $^{44}$.

En su dilatada etapa como canciller de Alfonso VIII, y sobre todo en la última década, Diego García contó con mayores efectivos y con una estructura orgánica más perfeccionada; por ejemplo, se diferencia ya entre el notario y el "scriptor" o "subnotario", éste como oficial encargado de la materialización del documento. Asistieron al canciller como notarios, primero, el ya conocido y brillante magister Mica (1192-1197) ${ }^{45}$ y, a continuación, a la vez, Petrus (1198-1204) y Dominicus, abad de Valladolid (1197-1210), para concluir con Petrus Poncii (1210-1214). Excepcionalmente, además, entre febrero y julio de 1193, prestaron servicio unos oficiales $-\mathrm{Lu}$ pus, Almericus, Rodericus Pauli y Iohannes Dominicus - con rango de "notarios del canciller". Y, a partir de 1204, como decíamos, aparecen trabajando también en la cancillería castellana hasta siete subnotarios: Paschasius (1204-1205), Petrus Sancii (1207), Iohannes (1209-1212), Petrus y Dominicus Alvari (1209-1214) ${ }^{46}$, más Dominicus Sancii (1213) y Rodericus (1214); la mayoría de ellos proseguirán prestando servicios al nuevo monarca Enrique I.

En síntesis, podemos rematar este apartado reiterando que la cancillería de Alfonso VIII fue diseñando su estructura y haciéndose a sí misma, cuantitativa y cualitativamente con el paso de los años durante aquel largo reinado. Y constatando además el evidente influjo de la cancillería pontificia en la castellana ${ }^{47}$, al igual que en la mayoría de las cancillerías reales europeas del momento. También se da en este tiempo una rivalidad de influencias entre las cancillerías leonesa y castellana (con claro predominio de la primera sobre la segunda durante las décadas iniciales del reinado del monarca ${ }^{48} \mathrm{y}$, a la inversa, en las siguientes décadas, prácticamente a partir de la entronización en León de Alfonso IX). Pero, sin duda, lo más resaltable de la cancillería castellana de Alfonso VIII, como ya adelantamos, fueron los notables logros conseguidos - todos ellos en la fase del canciller Raimundo- como la innovación del empleo de la rueda, del sello de plomo pendiente en determinados documentos, caso del privilegio rodado, y del emblema parlante (el "castillo", de Castilla, en el

${ }_{43}$ A. Millares, ob. cit., pp. 276-280.

44 A. Millares, ob. cit., pp. 284-287.

${ }^{45}$ Principal artífice, en esta segunda fase, del documento 5 de la colección.

${ }_{46}$ Autor material del documento 6 de nuestra colección.

47 Vid. SAnz Fuentes, Ma .J.: "La influencia de la cancillería pontifica en las cancillerías reales castellano-leonesas", Roma y la península Ibérica en la Alta Edad Media: la construcción de espacios, normas y redes de relación, de S. Domínguez Sánchez y Klaus Herbers (coords.). León, 2009, pp. 81-90.

${ }^{48}$ Hecho justificado, en parte, por la tutela ejercida por el rey leonés Fernando II sobre su sobrino Alfonso y todo el reino castellano, al menos hasta su mayoría de edad. Y también porque el cabildo compostelano siguió siendo el principal responsable de la expedición de los documentos reales del reino de León. 
reverso), aparte el nacimiento de la carta de mandato como nuevo tipo documental, más breve y con menos formalidades.

\section{LOS PRIVILEGIOS RODADOS DE ALFONSO VIII EN LA COLECCIÓN MEDINACELI (1175-1211)}

Son seis los privilegios rodados de Alfonso VIII que contiene la colección Medinaceli, todos ellos de concesión o merced, que abarcan un período cronológico amplio del reinado, el delimitado entre 1175 y 1211 (en concreto, suscritos los años 1175, $1177,1180,1188,1195$ y 1211 ${ }^{49}$. En la elaboración de estos documentos participaron los cuatro cancilleres que tuvo Alfonso VIII durante su dilatado reinado, a los que ya conocemos (Raimundo, Pedro de Cardona, Gutierre Rodríguez y Diego García), así como con algunos de los notarios más relevantes con los que contó la cancillería regia durante ese largo período (Pedro, Pedro de la Cruz, Gerardo, Mica y Pedro Ponce), además de un subnotario (Domingo Alvarez) ya en la etapa final del reinado.

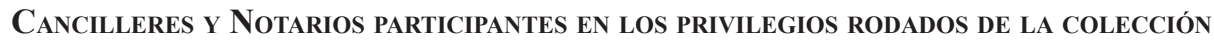

$$
\text { Raimundvs (1161-67 y 1170-78) }
$$

1175 (=Petrus, regis notarius (1170-76). Raimundo, existente cancellario, scripsit).

1177 (=Petrus de la Cruce*, regis notarius (1167-78) - Raimundus, existente cancellario, scripsit).

Petrus de Cardona (1178-1182)

1180 (Magister Geraldus*, regis notarius (1178-82). Petro de Cardona, existente cancellario, scripsit).

\section{GUTERRIVS RODERICI (1182-1192)}

1188 (=Magister Mica*, regis notarius. Guterrio Roderici, existente cancellario, SCRIPSIT).

\section{Didacvs Garsie (1192-1214)}

1195 (=Magister Mica*, domini regis notarius, SCRIPSIT. Didaco Garsie, existente cancellario)

1211 (=Petrus Poncii ${ }_{*}$, domini regis notarius. Didaco Garsie, existente cancellario. Dominico Aluari, subnotario, scribere iussit).

* Aparte los cancilleres, todos importantes y especialmente Raimundo, los notarios que ejercieron un papel más relevante en la cancillería alfonsina son los que resaltamos con asterico, todos ellos participantes en el proceso de elaboración de los privilegios rodados de la colección aquí presentada.

La lengua utilizada en todos los documentos intitulados por Alfonso VIII será el latín, como no podía ser de otro modo en aquella época - aunque ya por poco tiempo- ${ }^{50}$. Un latín complejo, aunque más culto que el anterior, que ha sido denominado

49 Aquí se citarán con el número que les corresponde dentro de la colección, del 1 al 6.

50 La adopción de la lengua vernácula se produjo en Castilla durante el segundo cuarto del siglo XIII. El primer privilegio rodado conocido, cuyo cuerpo está escrito en castellano, data de 29 noviembre 
por Pérez González "medieval cancilleresco", muy limitado temáticamente y ya con notables influencias de la lengua romance castellana ${ }^{51}$.

El soporte empleado es siempre el pergamino, usual por entonces para todo tipo de documentos y más para aquellos a los que se les quería imprimir un carácter más solemne $^{52}$. Para cada privilegio se utiliza una porción de pliego de pergamino de diferente grosor, pautado y de formato variable, si bien aún las proporciones del privilegio rodado no llegan a adquirir los enormes tamaños que caracterizarán a este tipo documental en los siglos bajomedievales. El promedio de tamaño de los diplomas de nuestra colección viene a ser unos 315 x 365 milímetros, más 50 de las plicas.

Las tintas empleadas son metaloácidas ferrogálicas, de uso general en aquella época. Su colorante surge de la reacción química de un ácido con un metal. El óxido del metal, producido por el ácido, da color a la tinta a la vez que graba el pergamino, dificultando su borrado cuando le cae agua y también el rasgado. La que más abunda es la tinta sepia u ocre - junto a la negra de carbón o negro de humo-, cuya receta de fabricación eran unos molidos y cocidos de vidriolo como colorante, de agallas de roble y encina como mordiente, de goma arábiga como espesante y aglutinante, y de agua clara y vino blanco como disolvente, licuante y conservante ${ }^{53}$.

Las plumas más empleadas para escribir estos privilegios fueron las de buitre, cuervo, pelícano, cisne, pato y - sobre todo- de ánsar u oca, porque eran duras, flexibles, incorruptibles por las tintas, satinadas, delgadas e idóneas precisamente para dejar correr las tintas utilizadas ${ }^{54}$.

La disposición del texto de estos privilegios rodados de Alfonso VIII en el pergamino es muy uniforme a lo largo del reinado ${ }^{55}$. El conjunto de la superficie está

de 1233, y el primero completo es de 23 de abril de 1250.

51 Vid. Pérez GonzÁlez, M.: El latín de la cancillería castellana (1158-1214). Salamanca-León, 1985, pp. 251-255. Y, por comparación, cfr. el de E. PÉREz RodríGuEz: El latín en la cancillería de Fernando II. León, 1986.

52 Pronto el pergamino empezará a convivir con el papel en las cancillerías reales hispanas. Es en el siglo XIII, durante los reinados de Jaime I en Aragón y de Sancho IV, cuando empliece a usarse pues Alfonso X legisla su empleo pero no lo usa en su cancillería. De todas formas el papel nunca se empleará en la confección del privilegio rodado - ni en la carta plomada, etc.- precisamente por esa solemnidad que se le quería otorgar al documento. Vid. C. CRespo Nogueira, "El papel, soporte gráfico desde la Edad Media a la época actual", en Actas de las I Jornadas de Archivística "El papel y las tintas" (Huelva, 1994), pp. 39-46; o el más reciente trabajo de I. GArcía DíAZ, y J.A. MontAlbán JimÉNEZ, "El uso del papel en Castilla durante la baja Edad Media", Actas del VI Congreso Nacional de Historia del Papel en España (Valencia, 2005), pp. 399-418.

53 Más sobre estas tintas en el manual y laminario de Paleografía de Romero Tallafigo, M.; Rodríguez Liáñez, L.; y SÁnchez González, A.: Arte de leer escrituras antiguas: Paleografía de lectura, $3^{\mathrm{a}}$ edic. Huelva, 2006 - p. 45. El calígrafo Juan de Yciar apuntaba en el siglo XVI la siguiente receta para la tinta de pergamino: "Tómese un azumbre de vino blanco lo mejor que se pudiere haber; y cuatro onzas de vidriolo de Flandes: y cuatro onzas de agallas de Valencia y tres onzas de goma arábiga. El vidriolo y la goma se han de moler muy bien, y las agallas no más de cuanto se hagan cuatro o cinco pedazos cada una. Y hecho esto ha se de hacer del azumbre de vino tres partes iguales y echar cada una en su vasija y en cada vasija echar los materiales, cada material por su parte; y han de estar a remojo por espacio de seis o siete días..." (J. DE YCIAR: Ortographia pratica. Zaragoza, 1548).

${ }_{54}$ Romero Tallafigo, M.; Rodríguez Liáñez, L.; SÁnchez González, A.: Ob. cit., pp. 47-48.

${ }^{55} \mathrm{Y}$ también así lo será invariablemente durante el dilatado periodo de vigencia del privilegio rodado a lo largo de toda la Edad Media, de casi cuatrocientos años, excepción hecha de aquellos últimos ejemplares de Enrique IV y los Reyes Católicos en forma de cuadernos, también de pergamino o vitela. 
claramente distribuido en dos partes: la superior, para colocar el texto nuclear del privilegio - un cuerpo de escritura inscrito en una caja bien proporcionada, con márgenes cuidados y unas líneas destacadas con las fórmulas de corroboración-, donde predomina la horizontalidad de los renglones (sólo alterada mínimamente por el Crismón inicial en el ángulo superior izquierdo del pergamino); y la parte inferior, en la que predomina la verticalidad que aportan la rueda - en el centro, como principal elemento de validación - y las dos columnas de confirmantes que la flanquean, una a cada lado. Por la parte inferior, cierra este encuadramiento del signo rodado la llamada "línea de cancillería" con los nombres del canciller y el notario o escribano intervinientes en el proceso de elaboración, escrituración y validación del documento.

Además, cada privilegio rodado encierra una serie de estrategias de comunicación pues tiene la condición de significante de un mensaje propagandístico del Poder establecido. El monarca, a través de estos documentos solemnes, saca partido no sólo del texto comunicado por medio de la escritura sino también de sus figuras visuales (caracteres externos), de los elementos orales patentes en su lectura en voz alta, así como de las fórmulas retóricas y figuras literarias oídas o leídas. Y como el hombre comunica sus mensajes normalmente por la vista (comunicación icónico-visual), por el oído (comunicación oral) y por la escritura (lectura), de ahí la valiosa recomendación del profesor M. Romero Tallafigo en el sentido de que, para entender históricamente las estrategias de estos privilegios, además de leerlos con conocimiento, hay que mirarlos detenidamente y escucharlos atentamente - leídos en voz alta- respetando las pausas y entonaciones que los calígrafos dejaron marcadas en las grafías antiguas $^{56}$.

Desde esta visión plena del documento, a continuación vamos a distinguir los mensajes textuales, visuales y auditivos de estos privilegios rodados de Alfonso VIII.

\subsection{MENSAJES TEXTUALES, O ASPECTOS DE CONTENIDO, DE LOS PRIVI- LEGIOS ALFONSINOS}

En las cancillerías reales, por lo general, todos los documentos eran esencialmente previsibles, de modo que cualquier creación personal quedaba truncada por las reglas de fórmulas de inicio, las cláusulas de cierre, o por la retórica y los tópicos del poder y de la persuasión.

El esquema formulístico del privilegio rodado emitido por la cancillería de Alfonso VIII no tiene grandes cambios a lo largo del dilatado reinado; muy al contrario, la uniformidad parece ser una de sus constantes más marcada.

Nuestros seis documentos, como todos los privilegios rodados alfonsinos, se inician con la llamada invocación simbólica a Dios —en señal de otorgamiento del rey en nombre de Cristo, principio y fin de todas la cosas- representada por el monograma del Salvador (el célebre crismón, con las dos primeras letras del nombre de Cristo en griego entrelazadas), monograma sobre el que nos extendemos en el siguiente

${ }^{56}$ Romero Tallafigo, M.: "El privilegio de Sanlúcar de Barrameda a Alfonso Pérez de Guzmán: Un diploma para leer, ver y oír", en Álvarez, C. y M. Romero (eds.): Archivos de la Iglesia de Sevilla (Córdoba, 2006), vol. 1, pp. 585-621 (587-588). 
apartado pues aparece siempre como telón que abre el escenario decorativo y visual de estos privilegios.

Al crismón, sigue a veces otra invocación verbal, como esta trinitaria de uno de nuestros privilegios:

- "In nomine sancte et indiuidue Trinitatis, que a fidelibus in unitate colitur et adoratur" (doc. 3).

En cambio, la mayoría de los privilegios alfonsinos - tras el monograma- comienza, unas veces con un preámbulo de diversa tipología $a^{57}$, como estos:

- "Decet regiam potestatem aliquem sibi et fideliter seruientem remunerare donis..." (doc. 1).

- "Inter cetera pietatis opera precipuum est et regibus specialiter conueniens loca que pia actio instituit uenerari ac diligere, et earum possesiones augmentare, presertim tamen ea in quibus Christi milites ad anime laborant gloriam et ad christianorum militant defensionem" (doc. 3).

- "Cum disponente diuina clementia, nobis Aldefonso, Dei gratia regi Castelle et Toleti, karissimum filium nostrum dompnum Ferrandum, cuius anima sempiterna requie perfrui mereatur, regni nostri habere non licuit successorem, ad adquirendum sibi regnum celeste, modis quibuscumque possumus anelare, et debemus et uolumus, ut deuotionem suam et obedientiam, quam nobis semper toto corde, totis uiribus, nisus est exhibere, ex quo in terrenis non licuit in celestibus condigna retributio consequator" (doc. 6).

Otras veces, en sustitución del preámbulo ${ }^{58}$, lo que aparece son unas fórmulas notificativas como éstas:

- "Presentibus quam futuris notum ac manifestum esse uolo..." (doc. 2).

- "Tam presentibus quam futuris notum sit ac manifestum..." (doc. 4).

- "Presentibus et futuris notum sit ac manifestum..." (doc. 5).

Tras las partículas "ea propter", iccirco, idcirco, ideo y proinde", en los casos de preámbulo, o simplemente "quod" ${ }^{60}$ en los demás, figura la intitulación, donde los soberanos exhiben su legitimidad a través de dos fundamentos: la fórmula divina del poder "gratia Dei..." y la extensión de dominio con la relación de los territorios sobre los que ejercen su soberanía. En los privilegios de Alfonso VIII, además del nombre del rey y sus títulos de dominio ("ego Adefonsus, Dei gratia Rex Castelle" -docs. 1 y 2-, "ego Adefonsus, Dei gratia Rex Toleti et Castelle" -doc. 3-, "ego Alde-

${ }^{57}$ Un pequeño trabajo sobre los preámbulos en la documentación intitulada por este monarca es el de M ${ }^{a}$.J. SAn Fuentes “Cancillería y cultura: los preámbulos en la documentación de Alfonso VIII", en Alfonso VIII y su época, pp. 387- 391.

58 Se comprueba que casi nunca aparecen juntas, todavía, las que serán con el tiempo las tres primeras fórmulas del privilegio rodado (invocación, preámbulo y notificación).

${ }^{59}$ Docs. 1,3 y 6.

60 Docs. 2,4 y 5. 
fonsus, Dei gratia Rex Castelle et Toleti" -docs. 4, 5 y 6-61) figura también siempre, desde el 17 de septiembre de 1170, el de la reina, su esposa ("...una cum uxore mea Alienor Regina") ${ }^{62}$ y, según las circunstancias de cada momento, los de los infantes, preferentemente el heredero de la Corona ("...et cum filio meo Ferrando..." -doc. 5-, "karissimum filium nostrum dompnum Ferrandum" -doc. 6-, "...et cum filio nostro dopmno Henrico..." -doc. 6-, etc. $\left.{ }^{63}\right)$.

En algunos documentos, a modo de exposición, se hace constar la voluntad soberana de otorgar el privilegio con fórmulas varias de distinto tipo: motivación - por ejemplo, "... pro animabus parentum meorum et salute propia" (docs. 3 y 5) -, la tradicional fórmula de espontaneidad "...libenti animo et voluntate spontanea" (docs. 2 y 3), ruegos ("ac petitionem domini...") e incluso puede argumentarse motivos o circunstancias históricas coetáneas.

La disposición encierra, obviamente, la determinación del objeto de la donación o concesión otorgada por el monarca, especificando a veces los términos y condiciones en que se efectúa dicha merced real. Esta parte dispositiva se inicia generalmente con los verbos, en primera persona de presente, "dono et concedo..." ${ }^{64}$, o con la fórmula "facio cartam donationis et concessionis..." ${ }^{65}$, seguida de la dirección o nombre del destinatario del documento a quien se le otorga el privilegio, a veces haciendo constar las razones que le hacen acreedor de la merced recibida ("pro multis seruiciis que uos dompno...-nombre-..., mihi deuote ac fideliter fecistis..."). Siempre el dispositivo recoge la extensión de la concesión ("cum castello et uilla, cum collaciis, terris, uineis, pratis, pascuis,...") y, en ocasiones, se especifica el carácter de la propia concesión ("ut eam iure hereditario in perpetuum habeatis..." o similar), como ocurre en la mayoría de nuestros documentos.

A continuación aparecen las cláusulas sancionales, que siempre comienzan por la condicional "si quis...", como las típicas conminatorias de penas espirituales (excomunión, condena eterna, ira divina, participación con Judas en el infierno, maldición, etc.) y las sanciones temporales (pago de multa, del doble del daño causado,...) contra quien se atreva o esté dispuesto a contravenir lo promulgado por el rey en el cuerpo del documento. Las cláusulas que aparecen en los privilegios de nuestra colección son las siguientes:

61 Otras intitulaciones reales que usó la cancillería de Alfonso VIII, algunas con mención a su progenitor, fueron: "Rex Castellonarum", "Hispanie regi", "Rex Hispaniarum", "Rex in Castella, et in Strematura et in Toleto", "Rex Castelle et Extremadure", "Rex Sancii filius", "Rex Castelle, domini Sancii, bone memorie famosissimi Hyspaniarum regis, filius", "Illustris et sane memorie regis Sancii filius, rex et dominus totius Castelle", "Rex Castelle, Sancii generosi regis filius", etc.

62 La reina doña Leonor, por su parte, encabeza la intitulación en un privilegio — antes citado- que fue suscrito en Toledo el 30 de abril de 1179 ("...ego Alienor, Dei gratia Regina Castelle, unam cum coniuge meo rege Aldefonso". Cfr. J.A. GARcía LujÁn, ob. cit., II, pp. 301-302, doc. 119).

63 Estos documentos nos suministran datos de todos los miembros de la familia real, principalmente los natalicios y óbitos (Vid. P. Ostos, ob. cit., p. 127).

64 Docs. 1, 2 y 5; también en plural: “donamus... et concedimus..." (doc. 6). U “offero, dono et concedo..." (doc. 4). Si se tratase de la confirmación de una merced anterior aparecerían los verbos "concedo et confirmo...".

65 Doc. 5. También "facio cartam donationis, concessionis et stabilitatis...” (doc. 3). 
- "Si quis uero huius mee donationis paginam in aliquo rumpere uel diminuere uoluerit, iram Dei omnipotentis plenarie incurrat et regiae parti $C$ libras auri puri et uobis uel ei qui uocem uestram habuerit, prefatam Paracollos duplatam in cauto persoluat" (doc. 1).

- "Si quis uero hanc cartam in aliquo rumpere uel diminuere temptauerit, iram Dei omnipotentis plenarie incurrat et regiae parti mille aureos, et uobis uel uocem uestram pulsanti prefatam uillas dupplatas in cauto persoluat" (doc. 2).

- "Si quis uero huius mee donationis et concesionis paginam in aliquo rumpere, inquietare uel diminuere presumpserit, iram Dei omnipotentis plenarie incurrat et cum Iuda, Domini proditore penas in inferno patiatur eternas, et insuper regie parti decem millia aureorum in cauto persoluat, et uobis fratribus Calatrauensis ordinis uel uocem uestram pulsanti damnum quod intulerit duplicatum restituat" (doc. 3).

- "Si quis uero hanc cartam infringere uel diminuere presumpserit, iram Dei omnipotentis plenarie incurrat et insuper regie parti mille aureos in coto persoluat et dampnum quod uobis intulerit dupplatum restituat" (doc. 4).

- "Si quis uero hanc cartam infringere seu in aliquo diminuere presumpserit, iram Dei omnipotentis plenarie incurrat et cum Iuda, Domini proditore infernalibus mancipetur penis, et insuper regie parti mille libras auri purissimi in coto persoluat et dampnum quod uobis intulerit dupplatum restituat" (doc. 5).

- "Si quis uero de nostro uel de alio genere, quod non credimus, cartam istam in aliquo presumpserit impedire, iram Dei omnipotentis incurrat plenarie, et cum Iuda, Domini proditore penis subiaceat infernabilus, et insuper regie parti decem milia aureorum in cauto persoluat, et dampnum iam dicto monasterio illatum super hoc restituat duplicatum" (doc. 6).

Seguidamente, precedida de las palabras "Facta carta", aparece la data, tópica y crónica. La primera con indicación del lugar de otorgamiento del privilegio ("...in Conca", "apud Toletum...", etc.). La crónica expresa el año, con numeración romana según la era hispánica, y el día y mes por el sistema romano de kalendación la mayoría de las veces (“...era $M^{a} C C^{a} X V I I I^{a}$, XIV $V^{o}$ kalendas septembris", etc.). A veces - sobre todo en la fase final del reinado, con el canciller Diego García一, la palabra "era" se destaca escribiéndose en mayúsculas. Una particularidad diplomática de la cancillería es la indicación en la fórmula cronológica, a veces, de hechos destacados del reinado indicando el tiempo transcurrido desde su acaecimiento (del tipo "anno quarto ex quo Adefonsus rex serenissimus supra numinatus Concham fidei christianae uiriliter subiugauit" -doc. $3-)^{66}$.

${ }^{66}$ Los hechos relevantes del reinado de Alfonso VIII que más se citan en los privilegios como data histórica, aparte de éste de la conquista de Cuenca en 1177 -recordada en los documentos hasta 1182-, son la toma de Zorita (14 de mayo de 1169), las primeras cortes de Burgos al alcanzar la mayoría de edad (11 de noviembre del mismo año), la expedición contra Navarra y victoria sobre Sancho VI (durante un año, a partir de septiembre de 1173), la huida nocturna del propio monarca navarro del asedio en el castillo de Leguín (a lo largo de 1176), la firma de una paz o convenio arbitral con León (desde fines de agosto de ese mismo año), la recuperación del Infantazgo (1181, durante más de año y medio), el nacimiento del primer heredero don Sancho (entre el 5 de abril y la segunda quincena de julio de 1181, en que fallece), la ceremonia de entronización de Alfonso IX como rey de León (1188, con el acto de besar las manos del monarca castellano, puesto de relieve reiterativamente durante los tres años siguientes como gesto de sumisión e inferioridad de un reino al otro), el acuerdo matrimonial entre Conrado de Alemania y la primogénita de Castilla doña Berenguela (en julio de 1188, a pesar de que tal enlace no llegó a producirse),... y, por supuesto, la gran victoria de las Navas de Tolosa (el 16 de 
A la data sigue la cláusula de corroboración real, en la que los soberanos autorizan y confirman la merced, por lo común mediante la fórmula regnans, en la que se citan los dominios territoriales ("Et ego rex Adefonsus, regnans in Castella et Toleto..."), antes de corroborar y confirmar ("...hanc cartam manu propria roboro et confirmo...", "...hanc cartam, quam fieri mandaui, manu propria roboro et confirmo..." o "...hanc cartam, quam fieri iussi, manu propria roboro et confirmo...") ${ }^{67}$.

En ocasiones acompaña el anuncio del sello pendiente, que aún no especifica la materia pero sí en muchos casos contribuye a imprimir al documento mayor garantía de seguridad ("et ad maiorem illius firmitudinem eam propio sigillo munire mando" o, simplemente, con la alocución "sigillo meo munio"). No lo lleva ninguno de nuestros privilegios pues, todavía, su presencia es poco significatica - de los numerosísimos privilegios alfonsinos solo 27 tienen esta fórmula-.

Sigue a veces, en línea separada, la corroboración como confirmante del arzobispo de Toledo, en cuanto primado de España —o el primero de todos los arzobispos hispanos- (“...Toletane sedis archiepiscopus et Hyspaniarum primas, confirmat”). En esta colección los primados que aparecen son Cerebruno (1167-1180), Gundisalvo —o Gonzalo- Petrez (1182-1191), Martín López de Pisuerga (1192-1208) y Rodrigo Jiménez de Rada (1209-1247) ${ }^{6}$.

A continuación, los privilegios completan la zona de validación utilizando varios elementos, principalmente la suscripción real a través del nuevo signo rodado, en el centro, que caracteriza a este tipo documental, flanqueado a izquierda y derecha por las columnas de confirmantes donde se pone de manifiesto toda una jerarquía del poder eclesiástico y civil, como veremos en el próximo apartado.

Cierra el documento por la parte inferior, bajo la rueda, la llamada línea o fórmula de cancillería, con los nombres del canciller y notario o del escribano en un solo renglón o, a lo sumo, en dos; durante la etapa del notario Mica la palabra "scripsit" suele aparecer escrita en mayúsculas y con letras más decoradas (docs. 4 y 5).

Pero la firmeza del documento, más incluso que con la suscripción autógrafa o el signo real, se autentifica con el sello de plomo que lleva colgado o pendiente el privilegio al menos desde 1175, acuñado por el canciller o custodio de la matriz.

\subsection{MENSAJES VISUALES, O ASPECTOS FORMALES Y DECORATIVOS, DE LOS PERGAMINOS}

Cuanto más solemne sea un documento - $-\mathrm{y}$ el privilegio rodado lo es, durante la Edad Media, como ningún otro-, más códigos externos tiene para ostentar mejor la posición política y social del emisor (el monarca) con respecto a otros emisores, y

julio de 1212, puesta de manifiesto en los documentos ya hasta la muerte del monarca castellano, algo más de dos años después).

${ }^{67}$ Esta es la principal diferencia en la validación de los privilegios, que mientras los reyes autorizan y confirman las concesiones otorgadas, los infantes, el primado, los arzobispos, el mayordomo y alférez de la casa real y demás dignatarios civiles y eclesiásticos del reino, obviamente, sólo la confirman.

${ }^{68}$ Respectivamente en los documentos 2, 4, 5 y 6. 
para desplegar más propaganda y ostentación visual, sin necesidad de lectura inteligente.

Este aspecto visual de documentos de cancillerías del Poder se manifiesta magníficamente en el privilegio rodado, principalmente en la forma expresiva de la escritura, la ornamentación mediante el crismón y la rueda con sus concéntricas - una interior para el campo con el signo real y otra exterior para la suscripción con la leyenda-, las columnas de confirmantes - con sus posiciones de honor-y el sello de plomo pendiente.

\section{ANÁLISIS DE LA ESCRITURA}

La escritura utilizada en los documentos de esta colección, siempre esmerada, elegante y muy caligráfica, es la minúscula carolina de tipo redondo, muy regular, clara y armónica - para el caso del documento 3, que aún conserva los rasgos gráficos carolingios más genuinos ${ }^{69}$, sin apenas nexos ni ligaduras ${ }^{70}-$, pero ya con paulatina tendencia a convertirse en angulosa y quebradiza, que le imprimen un goticismo progresivo, o escritura conocida como carolina pregótica (docs. 1, 2, 4, 5 y 6$)^{71}$. Y es que, durante el largo periodo del reinado de Alfonso VIII de Castilla, la escritura hispana va a conocer ciertamente una transformación desde la escritura carolina hacia las formas más apretadas, con letras más altas que anchas, cuyas líneas curvas u onduladas se convierten en angulares y con abreviaturas de todas clases, rasgos más propios de la escritura gótica. Lo mismo ocurre en otras monarquías europeas del momento - como estudiara Gasparri para el caso de la Francia de Luis VI, Luis VII y Felipe Augusto, es decir, entre 1108 y $1223^{72}$, o Stienno para la escritura de la diócesis de Lieja ${ }^{73}$ - y que ocurre también, aunque aquí con una tendencia mayor a la cursividad que en Castilla, en el caso de los documentos intitulados en el vecino reino de León, como apunta Pilar Ostos, especialmente en los diplomas de Alfonso IX ${ }^{74}$.

Estos documentos de Alfonso VIII, aun cuando presentan la lógica diversidad de las diferentes manos que los pusieron por escrito en la cancillería regia, parecen tener en cierta forma lo que podíamos llamar un "estilo propio" pues se empieza a vislumbrar en Castilla la formación de una escritura cancilleresca, al igual que ocurría en otras monarquías hispanas y europeas - todas ellas influidas por la escritura de las bulas pontificias-, que es lo que Cencetti llamó "artificios cancillerescos" aplicados

${ }^{69}$ Con estos rasgos gráficos: $S$ alta, parecida a la visigótica, $b$ de dos trazos, $d$ de dos formas, una llamada minúscula y otra uncial, $g$ abierta en sus dos trazos principales, confundiéndose a veces con $\mathrm{z}, e$ de tres trazos, $i$ sin punto encima, y $t$ parecida a la c (el trazo horizontal no corta al vertical).

${ }^{70}$ Los nexos más frecuentes son los de $c t, r t$, nt y particularmente st. Y las abreviaturas son cada vez más abundantes, predominando el sistema de letras superpuestas.

${ }^{71}$ En los últimos modelos del siglo XIII, incluso en los de las últimas décadas del XII, se da esta escritura carolina de transición a la gótica conocida como pregótica o postcarolina.

72 Vid. F. Gasparri: L'écriture des actes de Louis VI, Louis VII et Philippe Auguste. Genève-Paris, 1973.

${ }^{73}$ Vid. J. STIEnNo: L'écriture diplomatique dans la diocèse de Liège du XI ${ }^{e}$ siècle au milieu du XIII ${ }^{e}$ siècle. Réflet d'une civilisation. Paris, 1960.

${ }^{74}$ Ostos Salcedo, P.: Ob. cit., pp.121-122. 
a la escritura carolina para conferirle un aspecto más característico y solemne ${ }^{75}$. Es la escritura que veremos progresivamente instalarse en esas cancillerías reales para los documentos más solemnes, como el propio privilegio rodado, a la que acompaña otro tipo de escritura más descuidada y con tendencia cada vez más acusada a la cursividad, utilizada para elaborar documentos que no requerían tanta solemnidad. Las dos formas de escritura cristalizarán después en sendos tipos góticos: el más sentado, que desembocará más adelante, a partir del reinado de Alfonso X el Sabio, en la llamada gótica de privilegios, canonizada para los documentos solemnes de la cancillería castellana - caso de estos privilegios, de los que recibe el nombre ${ }^{76}$, o de las cartas plomadas - ${ }^{77}$; y el cursivo, para la restante documentación de la cancillería, que evolucionará en las distintas góticas cursivas.

\section{EVOLUCIÓN DEL CRISMÓN}

Como ya adelantamos, un elemento figurado encabeza todos los privilegios rodados de Alfonso VIII, y consecuentemente los seis de nuestra colección, la invocación simbólica o monogramática que usaban los documentos más solemnes de la cancillería, lo que no era excluyente - como vimos- para que se diera también la invocación verbal en algunos de estos documentos (concretamente así ocurre en el no 3 de nuestra colección).

Se trata, pues, de una invocación a la divinidad que hace el monarca, representada por el crismón o monograma de Cristo ${ }^{78}$, con las dos primeras letras, "xi” (X) y "rho" (P), entrelazadas, de su nombre en griego (XPISTOS); le acompañan siempre las letras "alfa" (A) y "omega" $(\omega)$ en clara alusión a la cita apocalíptica de que Cristo es principio y fin de todas las cosas (Ap. 22,13). También lleva una estrella, de seis u ocho puntas, que simboliza la expansión del cristianismo por todas las direcciones (ecumenismo). En la parte baja de la P se inserta además, unas veces por delante y otras por detrás, una $\mathbf{S}$ en referencia al Espíritu $\operatorname{Santo}^{79}$. Las cuatro letras son bien visibles y culminan sus trazos con ápices triangulares. El espacio ocupado por el crismón - sin cerrar al principio y encuadrado después - viene a suponer la altura de tres a cinco líneas del texto.

Estos crismones tienen forma parecida a los del reino de León. Los cuatro primeros modelos (1-4) aparecen completamente abiertos, mientras que los dos últimos - uno del maestro Mica (modelo 5) y otro del subnotario Domingo Alvarez (modelo

75 Vid. G. Cencettr: Lineamenti di storia della scrittura latina (Bologna, 1954), pp. 204-205.

${ }^{76}$ Así la llamó Terreros y hoy también se le denomina «minúscula diplomática» y "gótica minúscula caligráfica", una escritura cuya vida perdura hasta el reinado de los Reyes Católicos, en el que el privilegio rodado dejó de emitirse.

77 Sobre ella profundizaremos en el siguiente estudio sobre esta colección, que ya estamos preparando, sobre los privilegios rodados del siglo XIII de la colección Medinaceli.

${ }^{78}$ Este símbolo, en sí mismo, es muy antiguo, pues ya lo utilizó el emperador Constantino en sus estandartes -el lábaro constantiniano- como señal de victoria. Se trata, por tanto, de un ejemplo de la adaptación cristiana de los signos y de las narraciones simbólicas precristianas.

${ }^{79}$ Los llamados crismones trinitarios añaden esta "S" para expresar la Santísima Trinidad. 
6) - se inscriben en un cuadrado o rectángulo y, en este último caso, ya empieza a decorarse levemente ${ }^{80}$.

En cuanto a la proporción, la tendencia progresiva de estos anagramas es de ser más altos que anchos (modelos 1 a 4), a ser más anchos que altos (modelos 5 y 6 ).
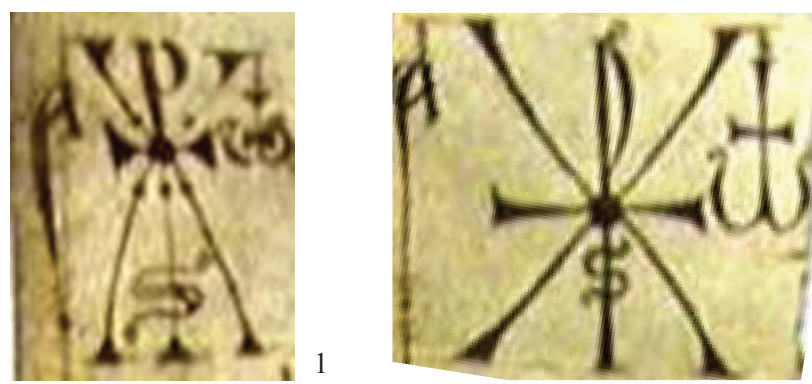

2
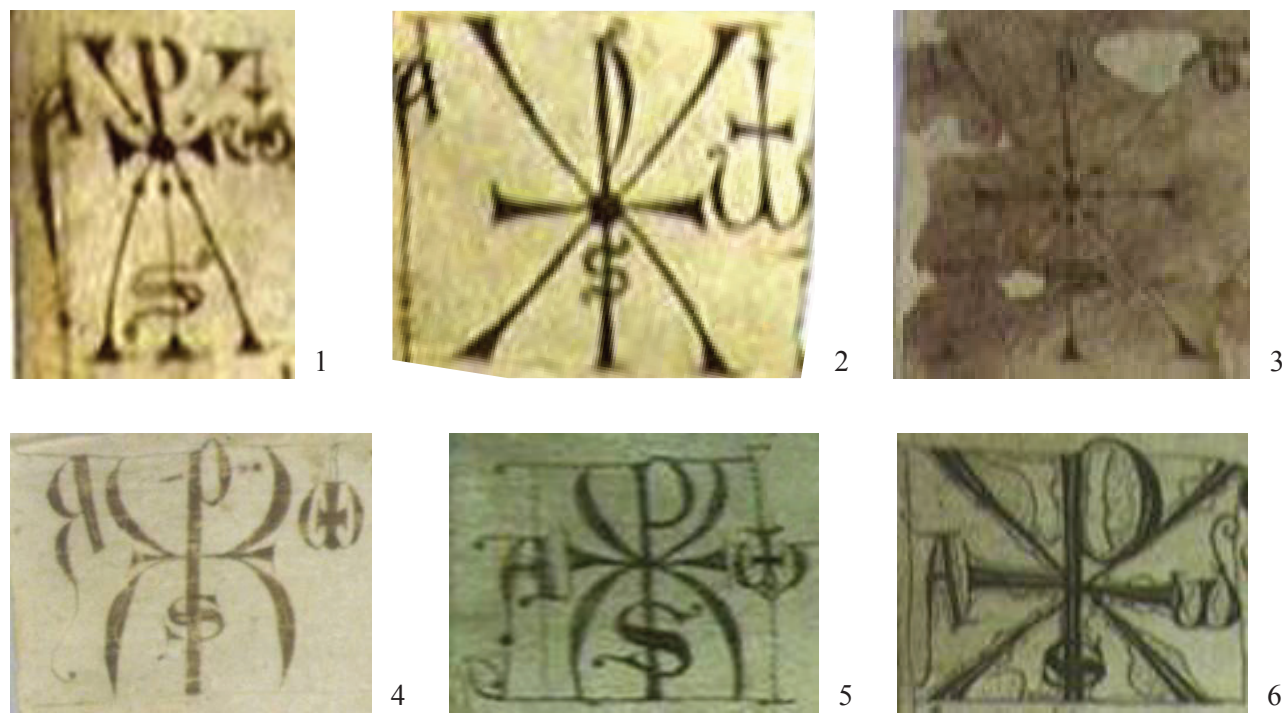

4

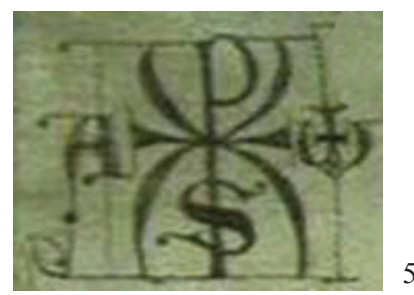

EVOLUCIÓN DE LA RUEDA

Pero mucho más que el crismón y, por supuesto, que el nombre del soberano y otras palabras relevantes del texto que aparecen resaltadas en mayúsculas, sin duda el más importante elemento visual del privilegio rodado es la rueda o signo circular, con rango de suscripción real, que se ubica en la parte inferior del pergamino ocupando el centro de la validación, como expresión de la afirmación por parte del monarca de la merced objeto del privilegio en cuestión - 0 , en otro caso, de su confirmación- ${ }^{81}$.

Los signos rodados de Alfonso VIII son de gran sencillez, están orlados por un anillo y ejecutados en tinta de un solo color. No son tan uniformes como los de la cancillería leonesa coetánea de Fernando II $^{82}$, sino ligeramente diferentes unos de

$80 \mathrm{Su}$ inscripción en un círculo no se dará hasta el reinado de Fernando III el Santo, y ya será característica de los privilegios rodados de la cancillería castellano-leonesa hasta su desaparición en tiempos de Juan II, relegada por la exclusiva invocación explícita o verbal.

81 Villar Romero, Ma .T.: Ob. cit., p. 13. En los seis privilegios de Alfonso VIII de nuestra colección no se da el caso de ninguna confirmación, pues todos son mercedes reales otorgadas por primera vez. El número 6 será confirmado, más tarde, por Alfonso X (doc. 7 de la colección Medinaceli).

${ }^{82}$ En León, el signum regis de Fernando II aumenta progresivamente de tamaño, pasando de 43 milímetros en los iniciales a 122 en algunos del maestro Bernardo, ya al final del reinado. Paralelamente aumenta también la perfección de la rueda, en lo que el propio Bernardo marca la cúspide: "sus leones están sometidos a un proceso de depuración, de ajuste a la realidad, de estudio de las proporciones y de los elementos expresivos" -que diría Ma .T. VILLAR ROMERO-, en un modelo que continuará tras él en la cancillería leonesa (ob. cit., p.17). 
otros. Los tamaños de la rueda ${ }^{83}$, del emblema regio, de la leyenda y de otros adornos presentan ligeros cambios a lo largo del dilatado reinado, además con las lógicas caracterizaciones propias de los respectivos notarios, subnotarios y otros oficiales y escribanos.

En cuanto a la representación heráldica del campo del signo real, durante el reinado del vencedor de las Navas siempre va a ser la cruz ${ }^{84}$, como herencia del signo de Alfonso VII el emperador - primer símbolo de la corona castellana, no personal del monarca sino del reino-, que usó luego Sancho III hasta pasar a la rueda con Alfonso VIII. Esta representación va evolucionando durante el largo reinado: en los privilegios rodados más antiguos, las cruces son muy pequeñas con respecto al campo del signo y están sostenidas por un astil muy largo (modelos 1,2 y 3 ); pero conforme el reinado avanza, la cruz va progresivamente aumentando de tamaño (modelos 4,5 ), e incluso lleva cuatro puntos - uno en cada ángulo del crucero- (modelo 5, del maestro Mica); al final del reinado vuelve a reducir su tamaño, como todo el campo del signo, en detrimento de la orla o anillo con la suscripción real, que aumenta considerablemente de grosor, además de empezar a decorarse, aunque aún muy tímidamente (modelo 6).

Precisamente la leyenda era una simple expresión del signo real, en los primeros documentos, con el texto "SIGNVM REGIS ILDE-/FONSI" (modelos 1-2, del canciller Raimundo) para, más adelante, irse completando con la expresión de dominio del soberano: "SIGNVM ILDEFONSI, REGIS CASTELLE" (modelos 3 a 6). Las palabras de la leyenda van separadas por segmentos sencillos o dobles en forma de cruz. El sentido de lectura de la leyenda dentro de la rueda, aunque siempre es sinestrógiro, presenta alguna variante en lo que concierne al arranque pues, mientras todos los del siglo XII comienzan en el punto inferior del anillo, a las 6 del punto del reloj (modelos 1 a 5), ya al final del reinado lo hace en el segmento que arranca a las 9 del punto del reloj (modelo 6).

Al contrario que en la cancillería leonesa que se sitúan en las columnas de confirmantes, alrededor del signo rodado, aunque todavía sin formar parte del mismo, aparecen en semicírculo las confirmaciones del mayordomo y alférez regios, con sus nombres de pila y apellidos, e incluso la especificación de cargo vacante - llegado el caso, como ocurre en el doc. 5 con la fórmula "Tunc temporis uacabat maiordomatus curie regis"- . Al principio del reinado normalmente el semicírculo es muy abierto y suele estar bastante separado del signo (modelos 2 a 4$)^{85}$; pero conforme el reinado avanza, la cancillería va acercándolo más al mismo (modelo 5), hasta ceñirlo para convertirse al final del mismo casi en un nuevo anillo (modelo 6) ${ }^{86}$.

${ }^{83}$ Los módulos de las ruedas de nuestros seis privilegios son los siguientes: 73, 95, 90, 65, 88 y 100 milímetros, respectivamente.

${ }^{84}$ Excepto en los primeros años del canciller Raimundo, que usa la flor de lis, si bien se trata de una representación que parece más bien vinculada al propio canciller (Vid. Ma .T. VILLAR Romero, $o b$. cit., p.19).

${ }_{85}$ Resulta curioso, no obstante, que el primer privilegio rodado de esta colección, obra del canciller Raimundo (1175), tenga una disposición muy circular junto al anillo con la suscripción real, más parecida a los del final del reinado.

${ }^{86}$ Sin embargo, como decimos, todavía no se encuentra el semicírculo encerrado en el signo rodado. No será hasta 1242, con Fernando III, cuando incorpore un segundo anillo externo, precisamente para 

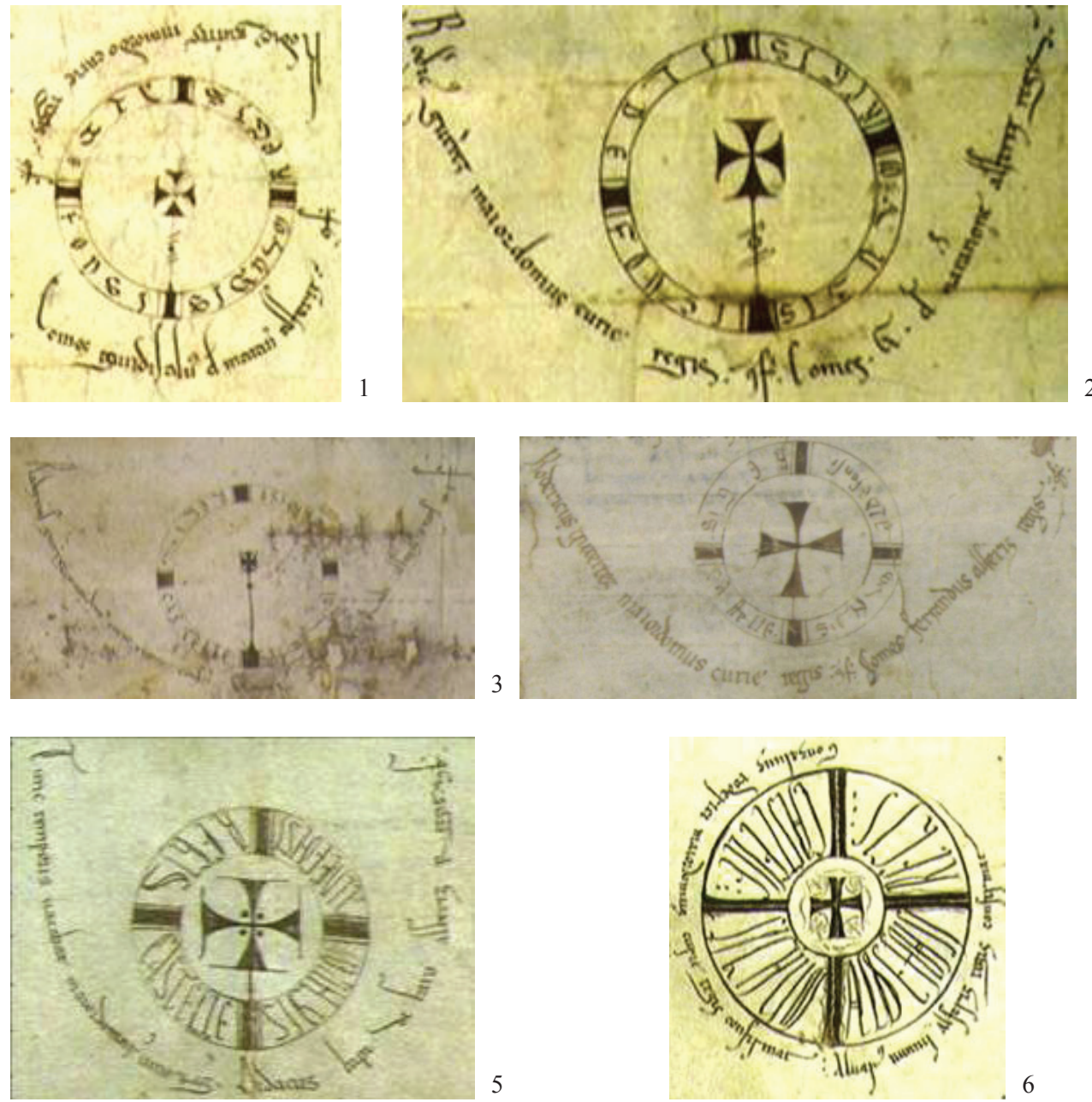

LAS COLUMNAS DE CONFIRMANTES CON SUS POSICIONES DE HONOR

Los privilegios rodados de Alfonso VIII, salvo contadas excepciones ${ }^{87}$ - la mayoría coincidentes con el primer período de indecisiones cancillerescas de la minoría del rey-, llevan dos columnas, una a cada lado de la rueda ${ }^{88}$. Ambas columnas se disponen bajo unas posiciones de honor, con las altas dignidades eclesiásticas a la

incluir las confirmaciones del mayordomo y alférez regios como leyenda.

87 Caso de los documentos 103, 309, 312 y 331 de la recopilación de J. GonzÁlEz (El reino de Castilla en la época de Alfonso VIII, tomo II), que tienen cuatro columnas.

${ }^{88}$ En la cancillería de Sancho III los privilegios signados fluctuaban en cuanto al número de columnas de confirmantes y en la colocación de los distintos dignatarios eclesiásticos y magnates del reino, pues los nobles -incluidos normalmente el mayordomo y el alférez- van a la izquierda del signo (no rodado), bajo los miembros de la familia real, y los eclesiásticos se sitúan a la derecha (vid. documentos 5, 6, 
izquierda de la rueda — desde el punto de vista del espectador-, mientras que los nobles y otros cargos de la corte se sitúan a la derecha. Tras cada nombre figura la palabra "confirmat", pero sólo el signo abreviado con, porque la $f$ con que se completa la abreviatura se prolonga todo lo largo de la columna. Han desaparecido, pues, los monogramas y signos que acompañaban a los nombres de cada uno de los testigos y confirmantes en épocas anteriores.

Paulatinamente fueron ordenándose mejor estas columnas para que su disposición contribuyera a dar una mayor prestancia y solemnidad al documento ${ }^{89}$. Esta disposición se generalizará a partir de entonces en las cancillerías de los sucesivos monarcas castellano-leoneses (si bien incrementando el número de columnas laterales hasta cuatro, ya con Fernando III el Santo).

\section{Sello de Plomo de Alfonso VIII}

Otra de las importantes novedades de la cancillería de Alfonso VIII fue instaurar el sello de plomo pendiente, al menos desde 1175 con el canciller Raimundo - como prueba la perforación romboidal que aparece en la plica de nuestro primer documento- ${ }^{90}$, con el fin de garantizar su autenticación pues, como ya adelantamos, era el elemento validativo que otorgaba verdadera firmeza y autentificación al privilegio ya que, como señala Fraenkel, proyecta sobre él la "dignidad real" ${ }^{91}$. El sello de plomo tiene origen bizantino ${ }^{92}$ y después extendió considerablemente por Italia durante la Alta Edad Media (dogos de Venecia, Papas, etc.), con el fin de validar los documentos más solemnes de las respectivas cancillerías ${ }^{93}$.

Los dos sellos de plomo del rey Alfonso VIII que se conservan de esta colección de privilegios rodados (el primero, de $1195 \mathrm{y}$, el segundo, de 1211) proceden de la

$10,11,14,15,17,18,19,21-26,28-30,35,37,39-41,43,46-48$ y 50 de la misma recopilación de J. GonZÁLEZ, ibídem, tomo II).

89 Es sabido que, en la mayoría de los casos, tales columnas sólo eran un ardid decorativo pues los confirmantes que aparecen en el documento ni estaban presentes en el momento de otorgarse el privilegio ni conocían, en la mayoría de los casos, tal otorgamiento. Cuando alguno de ellos estaba realmente presente en la conscriptio se le identificaba como "testigo confirmante" con las palabras "testis et confirmat" o simplemente "testes" (Vg. J. GonzÁlez, ibídem, doc. 76, tomo II, pp. 130-131).

${ }^{90}$ Parece que el primero que se conserva del monarca pende de un documento de 1176.

${ }^{91}$ Fraenkel, B.: La signature. Genèse d'un signe (Paris, 1992), p. 88.

92 Sobre los orígenes y desarrollo del sello de plomo, vid. J.M ${ }^{\mathrm{a}}$. de Francisco Olmos y F. NovoA Portela: Historia y evolución del sello de plomo. La colección sigilográfica del Museo Cerralbo (Madrid, 2008), pp. 23-41.

${ }_{93}$ En Aragón se emplea el sello de plomo a partir de 1210, en Portugal desde 1220, y en León no se utiliza hasta 1226 (Menéndez PIDAL, F.: Apuntes de Sigilografia española, p. 45). Aunque hay expertos que lo hacen exclusivo de las cancillerías reales y pontificias, en España existen también algunos no reales, en los extremos occidental y oriental, excepcionales sin duda, que pueden explicarse -según el propio Faustino Menéndez Pidal- como extensión de los usos vecinos. Así el sello cuadrado de plomo del cabildo catedral de Lugo, cuya existencia en 1289 consta por un documento, o la bula de plomo del conde de Ampurias Ponç Hug II que autoriza su testamento del año 1200, conservado en el propio Archivo Ducal de Medinaceli (ADM, Ampurias, leg. 1, nº 23). 
misma matriz, tienen un módulo de 50 milímetros y van pendientes de flecos de seda verde, azul y carmesí. El siguiente recuadro recoge su descripción.

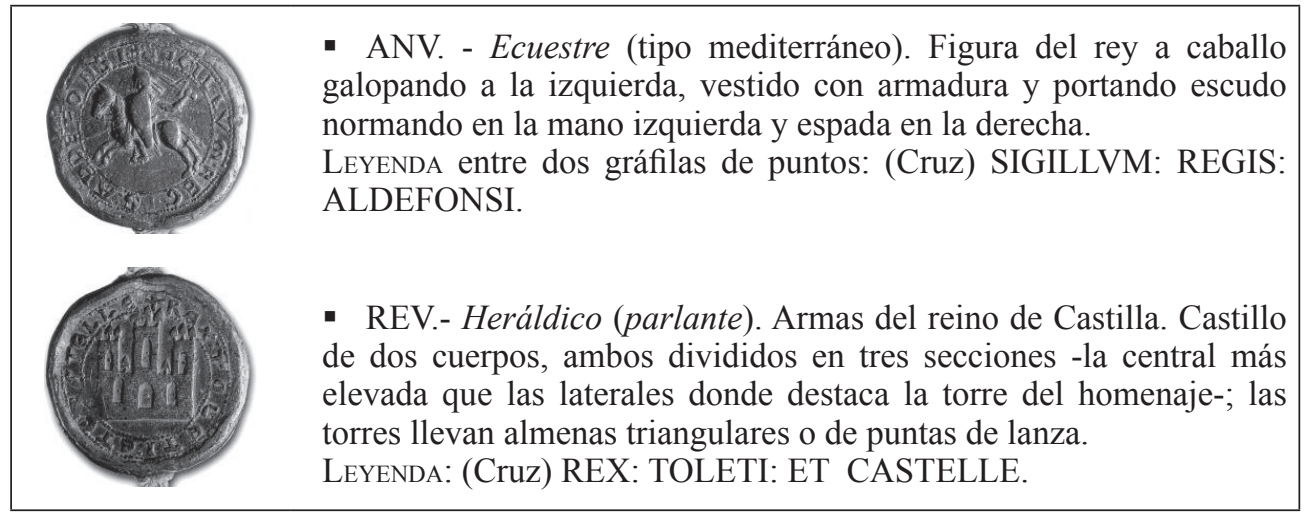

De este sello de plomo podemos destacar dos aspectos novedosos importantes: por un lado, la innovación de presentar en el anverso el tipo ecuestre de tradición mediterránea; y, por otro, la costumbre de presentar en el reverso el emblema heráldico del reino de carácter parlante (castillo, de Castilla) en lugar de la cruz, sin más, —que, como hemos visto, sí se mantiene en el signo rodado y así permanecerá hasta el reinado de Fernando III el Santo-.

El sello ecuestre mediterráneo del monarca, utilizado también en cera por Alfonso VIII al menos desde 1169, es innovador —en relación con el de su padre Sancho III y con el de los reyes leoneses- por cuanto el caballo galopa a la izquierda del espectador (mientras que esos otros siguen la tradición anglo-francesa en los que el rey cabalga en sentido contrario). Faustino Menéndez Pidal atribuye este cambio a la influencia que ejercía sobre el monarca castellano su tutor, el conde Manrique Pérez de Lara, señor de Molina, quien como su hijo, el conde Pedro Manrique, ya usaban el tipo ecuestre mediterráneo en sus sellos. También lo utilizó, desde 1150, el conde de Barcelona Ramón Berenguer IV ${ }^{94}$.

Por su parte, la costumbre de usar el emblema heráldico parlante del reino (que se inicia en Castilla en torno a 1175) ya la empleó, al menos desde cinco años antes que Alfonso VIII, la cancillería leonesa de Fernando II usando como signum regis en sus documentos el león pasante (que no rampante, como afirma la mayoría) $)^{95}$. Posteriormente, a partir de la segunda mitad del siglo XIII algunos privilegios rodados de la cancillería real castellana se validarían con sello de oro pendiente ${ }^{96}$.

94 Menéndez Pidal, F.: "Los sellos de los señores de Molina”, en Anuario de Estudios Medievales, 14 (Barcelona, 1984), pp. 104-110.

${ }_{95}$ Menéndez Pidal, F.: Apuntes de Sigilografía española, p. 35. Todos los leones que aparecen en los sellos, signos rodados y monedas de los reyes leoneses, en general, son pasantes (unas veces hacia la izquierda y otras hacia la derecha), con las excepciones de los escudos de Fernando II y Alfonso IX que aparecen en el Tumbo A de la catedral de Santiago, que son rampantes.

96 Es el caso, por ejemplo, de algunos privilegios otorgados por Alfonso X a la ciudad de Sevilla o a El Puerto de Santa María en su carta-puebla, a los que nos referiremos en el próximo artículo de esta serie sobre la colección Medinaceli que estamos elaborando. 


\subsection{LOS MENSAJES AUDITIVOS DE LOS DOCUMENTOS}

Estos documentos eran para ser leídos públicamente para conocimiento general, y más en una sociedad iletrada como la del siglo XII. Por eso son característicos también de estos privilegios rodados, como refiere Romero Tallafigo ${ }^{97}$, esos otros aspectos que acompañan al documento precisamente para resaltar, por ejemplo, el énfasis de voz en el empleo de mayúsculas y de las iniciales de determinadas palabras. También son muy importantes, en este sentido, las pautas, no ya sólo para establecer la lógica comprensión del texto sino también para recalcar su solemnidad en determinados momentos, sobre todo las pautas ceremoniales en palabras escritas en mayúsculas.

E incluso ese característico golpeo auditivo propio como en ningún otro tipo documental, del privilegio rodado a través de la lectura de las columnas de confirmantes con ese reiterativo y machacón "confirmat".

Como dijimos, en 1214 fallecía Alfonso VIII, concretamente la madrugada del 6 de octubre. Poco después, a los 26 días moría también la reina Leonor y era sepultada a su lado en el panteón real de Las Huelgas de Burgos. Con estas exequias, en los primeros días de noviembre de 1214 se cerraba el más largo reinado castellano y se abría - de nuevo - un período de inestabilidad bajo el reinado nominal y efímero de un rey niño, Enrique I (1214-1217). En total, el nuevo rey de Castilla en tan breve período sólo pudo intitular varias decenas de documentos, la mayoría privilegios rodados (45), según la recopilación hecha por J. González ${ }^{98}$. Sin embargo, de este monarca no existe ningún ejemplar en la colección Medinaceli.

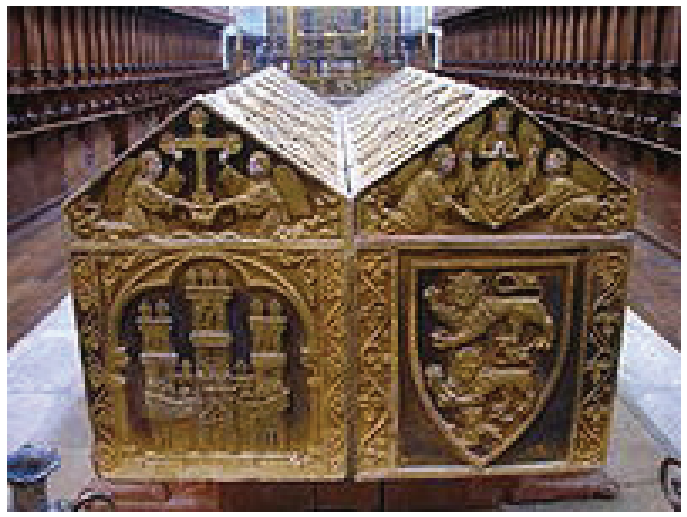

Sepulcro de Alfonso VIII y Leonor de Plantagenet en Las Huelgas

97 Romero Tallafigo, M.: ob. cit, pp. 612-616.

98 De los 55 documentos recopilados por el ilustre medievalista -los núms. 963 a 1015 y 1033 a 1035-, los 45 privilegios rodados son los documentos 964-969, 971-973, 976-994, 998-1004, 10071013, 1015, 1033 y 1035 (Vid. J. GonzÁlez, El reino de Castilla en la época de Alfonso VIII, tomo III). 


\section{TRANSCRIPCIONES Y AMBIENTACIÓN HISTÓRICA DE LA DOCU- MENTACIÓN}

Las normas de edición y transcripción que, con carácter general, utilizamos para los documentos de la colección ${ }^{99}$ siguen, preferentemente, los criterios fijados en 1984 por la "Commision Internationale de Diplomatique" ${ }^{100}$, combinados con alguna normativa española anterior ${ }^{101}$.

La edición se encabeza con un número de orden que se corresponde con el que tiene cada documento dentro de la colección en el Archivo Ducal de Medinaceli (en este caso del 1 al 6). Sigue la data, primero crónica adaptada al cómputo actual (año, mes, día, y -a veces, cuando lo lleva- día de la semana), y, luego, tópica con la indicación del lugar de expedición del documento ${ }^{102}$. A continuación aparece el regesto o resumen del documento, de forma breve y precisa ${ }^{103}$. Después se presentan los datos de identificación y descripción del documento: tradición documental en orden de antigüedad $^{104}$, signatura, medidas del pergamino, estado de conservación de la pieza, adherencia o no del sello pendiente, etc.). Por último, antes de proceder a la transcripción, se incluye el apartado de referencias de anteriores ediciones y citas/regestas del documento ${ }^{105}$. Otros aspectos del aparato crítico se colocan en notas al pie (notas cronológicas, archivísticas, etc.).

En cuanto a las normas de transcripción aplicadas destacamos las siguientes:

- Como principio general, hemos tenido en cuenta el respeto a la grafía original.

- En la puntuación y uso de mayúsculas y minúsculas seguimos el criterio actual; en concreto escribimos en mayúscula los antropónimos y topónimos.

- Se desarrollan todas las abreviaturas que presentan los textos originales.

- Las cifras indicadas en número romano las transcribimos conforme al original.

- Cada fin de renglón se representa con el signo /. Seguido de número volado, indica el orden del renglón que se inicia ${ }^{106}$.

— En lecturas dudosas, al término conjeturable le acompañará el signo de cierre de interrogación (?).

${ }^{99}$ Documentos que vamos a ir editando por reinados en sucesivos artículos.

100 Comisión Internacional de Diplomática, "Normes intemationales pour l'edition des documents medievaux", en Folia Caesaraugustana, 1. Zaragoza: Institución Fernando el Católico (CSIC), 1984. pp. 15-93).

101 Principalmente la normativa propuesta por la Escuela de Estudios Medievales del CSIC (Madrid, 1944), o F. Arribas Arranz, Paleografia documental hispánica (Valladolid, 1965, pp. 9-17) y A. Millares Carlo \& J. M. Ruiz Asencio, Tratado de Paleografía Española. (3 ${ }^{a}$ edic., Madrid, 1983, p. XII).

102 Cuando el topónimo ya ha desaparecido, ponemos el antiguo que figura en el original, entre comillas, seguido del topónimo actual entre paréntesis.

103 Por lo general, el nombre del rey con su fórmula de dominio (como autor del privilegio), el nombre del destinatario con su cargo, título u oficio, y el asunto o carácter de la merced.

104 Se cita siempre con A el documento original y con B y letras subsiguientes las diversas copias existentes, primero las auténticas y luego las simples, también por orden de antigüedad.

${ }_{105} \mathrm{Se}$ citan las publicaciones de referencia por orden cronológico de edición.

${ }^{106}$ La enumeración de renglones (cada 2, 3 ó 5) va en función de la longitud del documento. 
— En palabras con errores evidentes, normalmente por distracciones del escriba, al término le acompañará el signo (sic).

- Separamos o unimos palabras, sílabas o letras que aparezcan incorrectas en el documento, siguiendo los principios de la ortografía clásica.

— En caso de existencia de lagunas, si no pueden ser suplidas, ponemos el signo [...]; pero si pueden ser restituidas se indica el texto reconstruido dentro del corchete [ ].

- Los espacios en blanco los representamos aclarándolo dentro de corchete así: [(en blanco)]. Lo mismo hacemos en caso de rotura o desgarro del pergamino: [(rotura)]

— También aclaramos del mismo modo la señalización de anagramas y otros aspectos decorativos resaltables que aparezcan en el documento, así como las columnas de confirmantes, línea de cancillería, etc. Por ejemplo: [(crismón), $\left(1^{a}\right.$ columna $)$, (signo rodado)...].

— Las tachaduras, repeticiones y otras anomalías preferentemente las indicamos en el texto editado o bien aclarándolo en nota. Lo mismo para las adiciones e interlineados

- Para letras o palabras sobrantes y para los casos de omisiones y errores utilizaremos el signo $<>$.

- Las letras que presenten una forma especial en su grafía se transcribirán según el criterio actual. Por ejemplo, en textos latinos no se sustituye la $u$ por la $v$ cuando la primera tenga valor consonántico; y la $e$ caudada (ę) no la sustituimos por el diptongo ae sino que la representamos tal como figura en el documento.

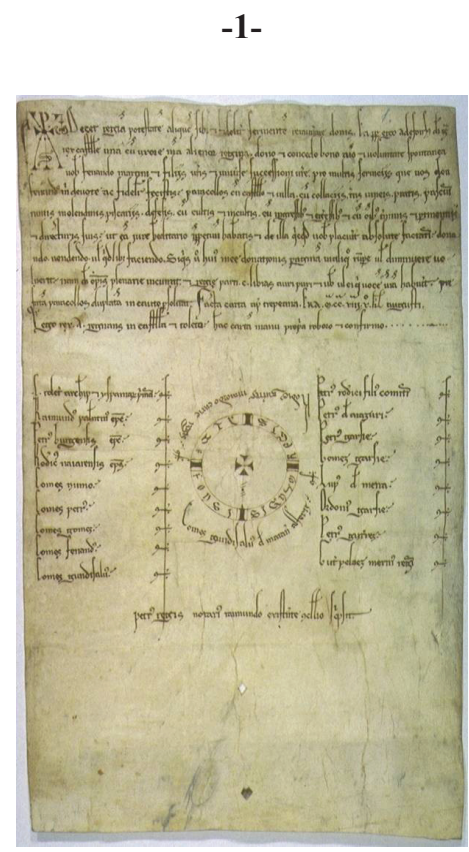

1175, julio, 23. “Trepeana” (Treviana).

Alfonso VIII, rey de Castilla, dona el lugar de "Paracollos" (Paracuellos de Jarama) con su castillo a Fernando Martínez y sus sucesores, en remuneración a los servicios prestados. 
A.- ADM, secc. Privilegios Rodados, $\mathrm{n}^{\mathrm{o}} 1$ (Procedencia: A.D.M., Paracuellos, 1-1). Pergamino 280 (ancho) x 400 (largo) $+65 \mathrm{~mm}$. (plica, con perforación romboidal, aunque falta el sello de plomo que llevaba pendiente). Buen estado de conservación. Texto en latín. Escritura carolina pregótica. Tinta ocre. Crismón y rueda (con la cruz, antiguo símbolo de la corona castellana) de la misma tinta, sin iluminar.

B.- AHN, Uclés, caja 260, $\mathrm{n}^{\circ} 17$, fol. 5. Copia del siglo XVI.

C.- AHN, Tumbo Menor de Castilla, lib. III, c. 98, pp. 333-334.

D.- RAH), colecc. M. Abella, 93. Copia del siglo XVIII.

EDIT.: GONZÁLEZ, J.: El reino de Castilla en la época de Alfonso VIII, tomo II, pp. 384386 (doc. 230); ROMERO TALLAFIGO, M.; RODRÍGUEZ LIÁÑEZ. L.; SANCHEZ GONZALEZ, A.: Arte de leer escrituras antiguas..., p. 112 y fotografía en p. 113 (doc. $10)$.

CIT.- LÓPEZ AGURLETA, J.: Vida del venerable fundador de la orden de Santiago y de las primeras casas de redempción de cautivos. Continuación de la apología por el hábito canónigo del patriarcha Santo Domingo en la misma orden (Madrid, 1731), $\mathrm{n}^{\mathrm{o}}$ 98, p. 43; PAZ Y MÉLIA, A.: Series de los más importantes documentos del Archivo y Biblioteca del Excmo. Sr. Duque de Medinaceli. 2 vols. = Series... I (Histórica). Madrid, 1915, p. 439; CONDE DE PEÑA RAMIRO: "De Madrid a Guadalajara", en Boletín de la Sociedad Española de Excursiones, Arte, Arqueología e Historia, XXXVII (III trimestre, 1929), p. 231; GARCÍA DEL ARROYO DE VAZQUEZ DE PARGA, C.: Privilegios reales de la orden de Santiago en la Edad Media. Catálogo existente en el Archivo Histórico Nacional. Madrid, s.a. [c. 1950], p. 73 (doc. 76).

«(Christus. Alfa. Omega). Decet regiam potestatem aliquem sibi et fideliter seruientem remunerare donis. Ea propter ego Adefonsus, Dei gratia, /rex Castelle, una cum uxore mea Alienor, regina, dono et concedo, bono animo et uoluntate spontanea, ${ }^{3}$ uobis Ferrando Martini et filiis uestris et uniuerse succesioni uestre, pro multis seruiciis que uos don /Ferrando, mihi deuote ac fideliter fecistis, Paracollos cum castello et uilla, cum collaciis, terris, uineis, pratis, pascuis, /riuiis molendinis, piscariis, defesis, cum cultis et incultis, cum ingressibus et egressibus, et cum omnibus terminis et pertinentiis $/{ }^{6}$ et directuris suis, ut eam iure hereditario in perpetuum habeatis, et de illa quicquid uobis placuerit absolute faciatis, dona-/ndo, uendendo, uel quidlibet faciendo.

Si quis uero huius mee donationis paginam in aliquo rumpere uel diminuere uo- / luerit, iram Dei omnipotentis plenarie incurrat et regiae parti $\mathrm{C}$ libras auri puri et uobis uel ei qui uocem uestram habuerit, pre- $/{ }^{9}$ fatam Paracollos duplatam in cauto persoluat.

Facta carta apud Trepeana, era $\mathrm{M}^{\mathrm{a}} \mathrm{CC}^{\mathrm{a}} \mathrm{XIII}^{\mathrm{a}}, \mathrm{X}^{\mathrm{o}}$ kalendis augusti.

Et ego rex Adefonsus, regnans in Castella et Toleto, hanc cartam manu propria roboro et confirmo.

(1 $1^{a}$ columna):

Cerebrunus, Toletanus archiepiscopus et Yspaniarum primas, confirmat.

Raimundus, Palentinus episcopus, confirmat.

Petrus, Burgensis episcopus, confirmat.

Rodericus, Naiarensis episcopus, confirmat.

Comes Nunio, confirmat.

Comes Petrus, confirmat.

Comes Gomez, confirmat.

Comes Ferrandus, confirmat.

Comes Gundisaluus, confirmat. 
(Signo rodado: Cruz): SIGNUM / REGIS / ALDE- / FONSI.

(Orlando la rueda, en semicírculo): Rod(er)icus Guterrez, maiordo(mus) curie regis, confirmat. Comes Gundisaluus de Marannon, alferiz, confirmat.

\section{( $2^{a}$ columna):}

Petrus Roderici, filius comitis, confirmat.

Petrus de Arazuri, confirmat.

Petrus Garsie, confirmat.

Gomez Garsie, confirmat.

Lupus de Mena, confirmat.

Ordonius Garsie, confirmat.

Petrus Guterrez, confirmat.

Guter Pelaez, merinus regis, confirmat.

(Línea inferior): Petrus, regis notarius. Raimundo, existente cancellario, scripsit».

$$
* * *
$$

\section{AMBIENTACIÓN HISTÓRICA}

El lugar de Paracuellos de Jarama, al parecer, se había incorporado a la jurisdicción de la mitra toledana desde tiempos de Alfonso VI con el arzobispo Bernardo de Sèdirac. Por su participación en la lucha contra los almorávides, el arzobispo de Toledo recibió como señorío el derecho a cobrar tributos y administrar justicia sobre la población.

Más tarde, por este privilegio rodado de 1175, el rey Alfonso VIII dona la villa y el castillo a su fiel servidor, el caballero D. Fernando Martínez de Hita, comendador de Uclés, en remuneración a los servicios prestados, para sí y sus sucesores.

Sin embargo, no se va a perpetuar el señorío de Paracuellos en poder de este linaje por cuanto, como veremos, el lugar sería donado veinte años después por el propio monarca castellano a la orden de Santiago (doc. 5).

\section{$-2-$}

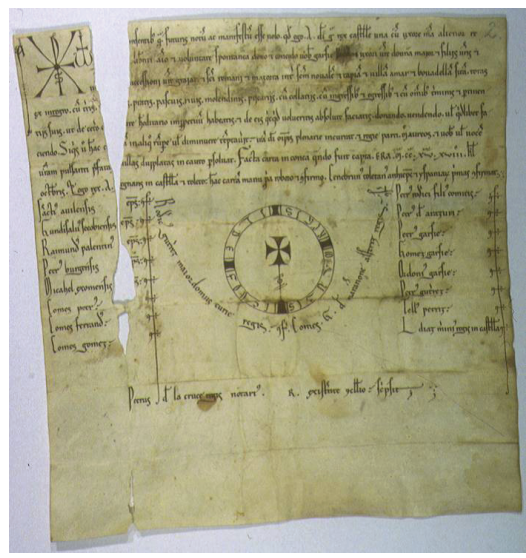

1177, septiembre, 14. Cuenca (“quando fuit capta”). 
Alfonso VIII, rey de Castilla, concede a García de Padilla y a su esposa doña Mayor, los lugares de Grajar (Grajal), San Román y Mazorra, con todos sus términos y pertenencias.

A.- ADM, Privilegios Rodados, $\mathrm{n}^{\circ} 2$ (Procedencia: A.D.M., secc. Adelantamiento de Castilla). Pergamino 375 x $330+55 \mathrm{~mm}$. Regular estado de conservación (documento algo deteriorado, con rotura por desgarro que afecta a una parte longitudinal del texto en la zona izquierda). Crismón y rueda de tinta. Falta el sello de plomo. Texto en latín. Tinta negra. Escritura carolina pregótica.

B.- RAH, colecc. Velázquez, 8. Copia simple del siglo XVII.

C.- RAH, colecc. Abella, 93. Copia simple, con nota tomada de Salazar y Castro atribuyendo la merced a García Fernández de Villamayor y no a García de Padilla.

EDIT.- GONZÁLEZ, J.: Ibidem, tomo II, pp. 474-475 (doc. 289).

CIT.- PAZ Y MÉLIA, A.: Series... I, p. 439.

«(Christus. Alfa. Omega). Presentibus quam futuris notum ac manifestum esse uolo, quod ego Adefonsus, Dei gratia rex Castelle, una cum uxore mea Alienor, re- $/^{2}$ [(rotura)gina], libenti animo et uoluntate spontanea, dono et concedo uobis, Garsie Padilla ${ }^{107}$ et uxori uestre donna Maior et filiis uestris et / u-/[(rotura)niuerse] successioni uestre, Grajar et Sancti Romani et Mazorra, inter Sanctum Noualem et Tapiam et Uilamamar et Bouadellam sitam, totas ${ }^{4}$ ex integro, cum terris, [(rotura) ¿uineis?], pratis, pascuis, riuiis, molendinis, piscariis, cum collatiis, cum ingressibus et egressibus, et cum omnibus terminis et pertinen- $/{ }^{4}$ tiis suis, ut de cetero e-[(rotura $)$ as iu- $]$ re hereditario in perpetuum habeatis, et de eis quicquid uolueritis absolute faciatis, donando, uendendo, uel quidlibet fa- $/{ }^{6}$ ciendo.

Si quis uero hanc [(rotura) cartam] in aliquo rumpere uel diminuere temptauerit, iram Dei omnipotentis plenarie incurrat et regiae parti mille aureos, et uobis uel uocem / uestram pulsanti prefatam $[($ rotura $) ..$.$] uillas dupplatas in cauto persoluat.$

Facta carta in Conca, quando fuit capta, era $\mathrm{M}^{\mathrm{a}} \mathrm{CC}^{\mathrm{a}} \mathrm{XV}^{\mathrm{a}}, \mathrm{XVIII}{ }^{\circ}$ kalendis $/ 8$ octobris.

Et ego rex Adefonsus, regnans in Castella et Toleto, hanc cartam manu propria roboro et confirmo.

Cerebrunus, Toletanus archiepiscopus et Yspaniarum primas, confirmat. /

\section{(1 ${ }^{a}$ columna):}

Sanctius, Auilensis episcopus, confirmat.

Gundisaluus, Secobrensis episcopus, confirmat.

Raimundus, Palentinus episcopus, confirmat.

Petrus, Burgensis [e]piscopus, confirmat.

Micahel, Exomensis [(rotura) episcopu]s, confirmat.

Comes Petrus, confirmat.

Comes Ferrandus, confirmat.

Comes Gomez, confirmat.

(Signo rodado: Cruz): SIGNUM / REGIS / ILDE- / FONSI.

(Orlando la rueda): Rodericus Guterrez, maiordomus curie regis, confirmat.

Comes Gundisaluus de Marannone, alferiz regis, confirmat.

107 Algunos autores, como el ya comentado Salazar y Castro, atribuyen la merced regia a García Fernández de Villamayor, en lugar de a García de Padilla en razón de que el apellido está sobre raído en el pergamino. Sin embargo, esta atribución no es posible, primero, porque en ningún caso hubiera cabido ese largo apellido -incluso abreviado- en el espacio asignado en el documento y, segundo, porque entonces el original no se habría custodiado en el Archivo Ducal de Medinaceli (García de Padilla sí es ascendiente de los Medinaceli por la línea de los Manriques de Padilla, adelantados mayores de Castilla, mientras que García Fernández de Villamayor no lo es). 


\section{( $2^{a}$ columna):}

Petrus Roderici, filius comitis, confirmat.

Petrus de Arazuri, confirmat.

Petrus Garsie, confirmat.

Gomez Garsie, confirmat.

Ordonius Garsie, confirmat.

Petrus Guterrez, confirmat.

Tellus Petriz, confirmat.

Lupus Diaz, merinus regis in Castella, confirmat.

\section{(Línea inferior):}

Petrus de la Cruce, regis notarius. Raimundus, existente cancellario, scripsit».

\section{AMBIENTACIÓN HISTÓRICA}

Por este privilegio rodado de 1177, Alfonso VIII concede a García de Padilla y a su esposa doña Mayor, los lugares de Grajar (Grajal), San Román y Mazorra, con todos sus términos y pertenencias. No poseemos posteriores datos entre la documentación del ADM, lo que significa que no debió perpetuarse su posesión en la estirpe de los Padilla, que luego fueron adelantados mayores de Castilla.

$-3-$

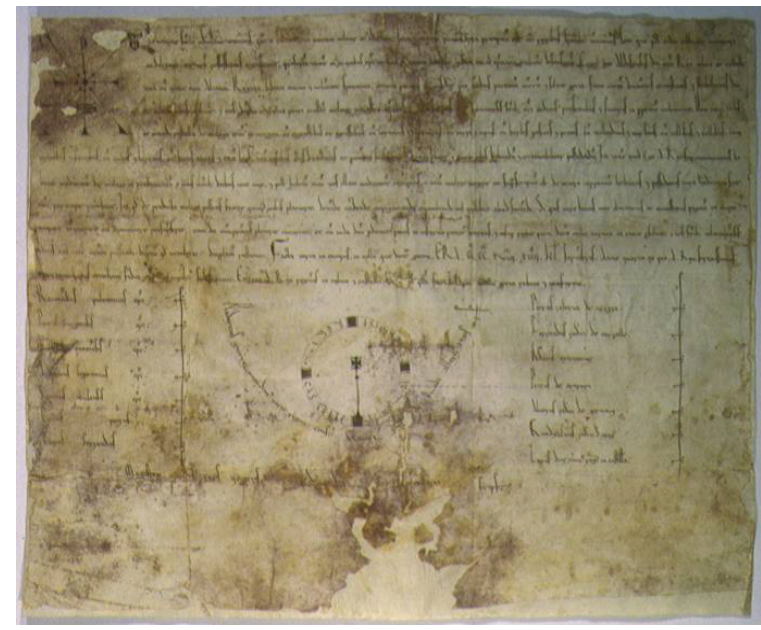

1180, agosto, 19. Gatón (de Campos).

Alfonso VIII, rey de Castilla, hace merced a la orden de Calatrava, en la persona de su maestre Martín Pérez (de Siones), del castillo de Malagón, con la condición de que la mitad permaneciera como préstamo en poder del propio monarca durante su vida, para pasar tras su muerte integramente a poder de la orden. 
A.- ADM, Privilegios Rodados, $\mathrm{n}^{\circ} 3$ (Procedencia: A.D.M., Malagón, 1-1). Pergamino 510 x $380+50 \mathrm{~mm}$. Mal estado de conservación (documento con manchas y con algunos fragmentos, que ha sido antiguamente restaurado aplicándosele otro pergamino debajo como reforzamiento). Crismón y rueda de tinta. Falta el sello de plomo que llevaba pendiente. Texto en latín. Tinta ocre. Escritura carolina.

B.- ADM, Malagón, 1-1. Copia del siglo XVIII, con traducción del privilegio latino al castellano a cargo de Eugenio de Benavides (1763, septiembre, 9. Madrid).

C.- AHN, Órdenes Militares, Registro de Escrituras de la Orden de Calatrava, I, sign. 1341 c, fol. 67.

EDIT.- GONZÁLEZ, J.: El reino de Castilla en la época de Alfonso VIII, tomo II, pp. 593595 (doc. 350).

CIT.- PAZ Y MELIA, A.: Series... I, p. 439; CORCHADO SORIANO, M.: El campo de Calatrava. III Parte: Los pueblos (Ciudad Real, 1982), p. 287; CAMPO REAL, F. del: Malagón, un señorío en el Campo de Calatrava: orígenes y evolución (Siglos XVIXVIII). Ciudad Real, 1997, pp. 23-24 y 667-668; RODRIGUEZ-PICAVEA MATILLA, E.: Documentos para el estudio de la Orden de Calatrava en la Meseta meridional castellana (1102-1302), Colecciones Documentales $n^{\circ} 2$ de «Cuadernos de Historia Medieval» (Madrid, 1999), doc. 57, p. 53.

«(Christus. Alfa. Omega). In nomine sancte et indiuidue Trinitatis, que a fidelibus in unitate colitur et adoratur. Inter cetera pietatis opera precipuum est et regibus specialiter conueniens loca que pia actio instituit uenerari $/^{2}$ ac diligere, et earum possesiones augmentare, presertim tamen ea in quibus Christi milites ad anime laborant gloriam et ad christianorum militant defensionem. Ea propter ego Aldefonsus, Dei gratia rex Toleti et Castelle, /una cum uxore mea Alienor regina, libenti animo et uoluntate spontanea, intitui pietatis ac misericordie, pro animabus parentum meorum et salute propia, facio cartam donationis, concessionis et stabilitatis Deo $/{ }^{4}$ et Calatrauensi militie, et uobis domno Martino Petri, eiusdem militie magistro, omnibusque succesoribus uestris et uniuersis fratribus uestri ordinis presentibus et futuris, in perpetuum ualituram. Dono itaque uobis /et concedo castellum de Malagon, totum et integrum, cum ingressibus et egressibus, cum terminis et frontariis, cum terris et aquis, cum herbis, pasquis et pratis, cum molendinis et eorum locis, cum collibus et uallibus, cum $/ 6$ montibus et fontibus, cum cultis et heremis, cum hortis, uineis et eorum locis, et cum omnibus aliis directuris et pertinentiis suis, iure hereditario libere et quiete uobis habendum et irreuocabiliter perpetuo possidendum, ita tamen quod ego Adefonsus, rex supra nominatus, ha-/beam medietatem de Malagon in prestimonium a uobis omnibus diebus uite mee, et post obitum meum uos illam medietatem recuperetis et totum Malagon integre, ut superius scriptum est, de cetero in perpetuum habeatis, et posideatis iure hereditario sine $/{ }^{8}$ omni participe et consorte, ita quod de predicto Malagon possitis facere quidquid uobis placuerit, donando, uendendo, impignorando, concambiando uel quidlibet aliud faciendo.

$\mathrm{Si}$ quis uero huius mee donationis et concesionis paginam in aliquo/rumpere, inquietare uel diminuere presumpserit, iram Dei omnipotentis plenarie incurrat et cum Iuda, Domini proditore penas in inferno patiatur eternas, et insuper regie parti decem millia aureorum in cauto persoluat, et uobis fratribus Calatrauensis $/{ }^{10}$ ordinis uel uocem uestram pulsanti damnum quod intulerit duplicatum restituat.

Facta carta in Campis, in uila que dicitur Gaton, era $\mathrm{M}^{\mathrm{a}} \mathrm{CC}^{\mathrm{a}} \mathrm{XVIII}^{\mathrm{a}}, \mathrm{XIV}^{\mathrm{o}}$ kalendis septembris, anno quarto ex quo Adefonsus rex serenissimus /supra numinatus Concham fidei christianae uiriliter subiugauit.

Et ego Adefonsus rex, regnans in Toleto et Castella, hanc cartam, quam fieri mandaui, manu propria roboro et confirmo. 


\author{
( $1^{a}$ columna): \\ Raimundus, Palentinus episcopus, confirmat. \\ Petrus, Burgensis episcopus, confirmat. \\ Micahel, Oxomensis episcopus, confirmat. \\ Ardericus, Segontinus episcopus, confirmat. \\ Sanctius, Abulensis episcopus, confirmat. \\ Comes Petrus, confirmat. \\ Comes Ferrandus, confirmat.
}

(Signo rodado: Cruz): SIGNUM / ALDEFONSI / REGIS / CASTELLE.

(Orlando a la rueda en semicírculo): Rodericus Guterrez, maiordomus curie regis, confirmat. Gomez Garsie de Roda, alferiz regis, confirmat.

\title{
(2a columna):
}

Petrus Roderici de Açagra, confirmat.

Ferrandus Roderici de Truxello, confirmat.

Didacus Xemenez, confirmat.

Petrus de Arazuri, confirmat.

Alvarus Roderici de Guzman, confirmat.

Gundisaluus Roderici de Açagra, confirmat.

Lupus Diaz, merinus regis in Castella, confirmat.

\section{(Línea inferior)}

Magister Geraldus, regis notarius. Petro de Cardona, existente cancellario, scripsit».

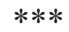

\section{AMBIENTACIÓN HISTÓRICA}

Durante la época islámica, Malagón se perfila como una plaza fuerte en el camino de Calatrava a Toledo con la construcción de un castillo por parte de los árabes, que llaman al poblado con su nombre actual. Al parecer, el primer señor del castillo de Malagón es Ibn Ardabalis, quien gobierna la población con mano dura, llegando incluso a enfrentarse personalmente con el propio califa de Córdoba Abderrahmán III. Pero Ardabalis acaba siendo reducido por las fuerzas leales al califa y es ejecutado en el año 912, siendo su cabeza expuesta públicamente en la mezquita cordobesa.

Es a principios del siglo XII cuando comienza el asedio cristiano y la reconquista de estas tierras manchegas. Así, en el año 1100 ocurre un episodio singular en las cercanías de Malagón: Enrique de Borgoña, yerno de Alfonso VI, es sorprendido con sus huestes por los árabes a los pies del castillo de Malagón y la expedición cristiana sufre un revés. Enrique se salva únicamente por su cobarde huída.

Alfonso VII conquistó finalmente estas tierras a los musulmanes y tomó Calatrava en 1147, anexionando al reino de Castilla ésta y todas las tierras de la Orden, incluída Malagón.

El castillo de Malagón se había levantado en la ladera de un cerro, hoy llamado "Morro de Malagón". El arzobispo de Narbona lo describía como no demasiado amplio, con una torre central y otras cuatro en las esquinas que se conectaban por fuertes paramentos de cal y canto.

La situación del lugar era importante por encontrarse a dos jornadas desde Toledo en el camino a Córdoba, cuando se modificó la ruta a Al-Andalus de la antigua vía romana. De 
ahí que se dilucidaran en Malagón varios hechos de armas durante la Reconquista, como la derrota comentada del conde de Borgoña. Después el lugar volvería a manos cristianas pues, en 1147, estaba guarnecido por huestes de Alfonso VII, y en poder de Castilla permanecería hasta la derrota castellana de Alarcos (1195).

En esa etapa, en la que se amplía su fortaleza, es cuando Malagón es entregada a la orden de Calatrava, en la persona de su maestre Martín Pérez de Siones, por medio de este privilegio rodado otorgado por Alfonso VIII en Gatón de Campos el 19 de agosto de 1180, en las condiciones que recoge el documento, es decir, en una mitad y reservándose el monarca castellano la otra en usufructo hasta su muerte.

Ocho años después, como comprobaremos en el documento inmediato, esas condiciones de la donación cambiarán y la pertenencia de Malagón a la orden de Calatrava será completa.

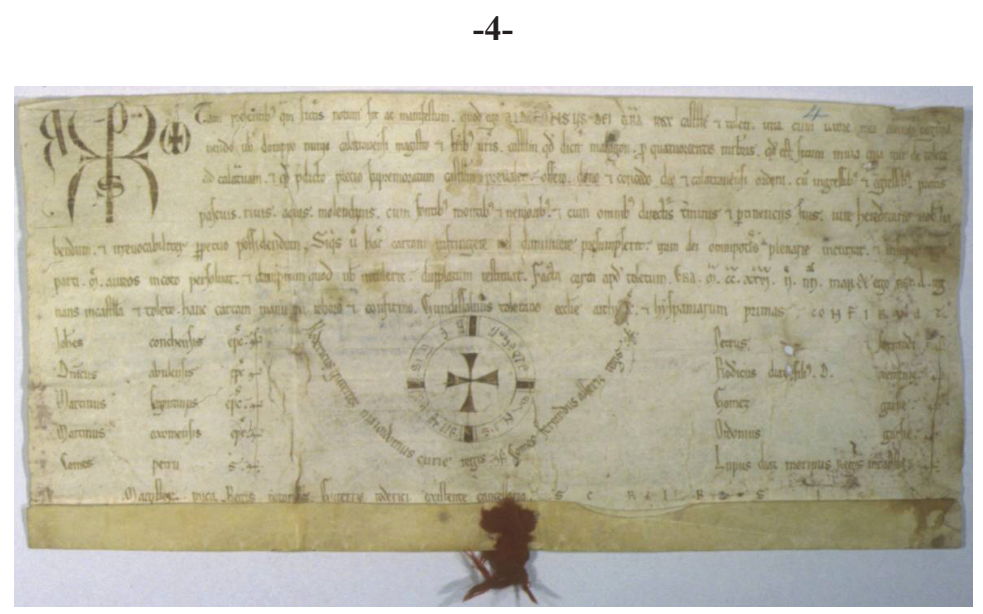

1188, mayo, 6. Toledo.

Alfonso VIII, rey de Castilla, vende a la orden de Calatrava y a su maestre Nuño todos los derechos que se había reservado sobre la otra mitad del castillo y tierra de Malagón, por 400 maravedis.

A.- ADM, Privilegios Rodados, $\mathrm{n}^{\circ} 4$ (Procedencia: A.D.M., Malagón, 1-2). Pergamino 435 x $210+25 \mathrm{~mm}$. Buen estado de conservación. Crismón y rueda de tinta. Falta el sello de plomo, aunque conserva los hilos granates de los que pendía. Texto en latín. Tinta ocre. Escritura carolina pregótica.

B.- ADM, Malagón, 1-2. Copia del siglo XVIII, con traducción del privilegio latino al castellano a cargo de Eugenio de Benavides (1763, noviembre, 9. Madrid).

C.- AHN, Órdenes Militares, Registro de Escrituras de la Orden de Calatrava, I, sign. 1341 c, fol. 108.

D.- RAH, colecc. Salazar, I-37, fol. 60 vto.

EDIT.- GONZÁLEZ, J.: Ibidem, II, pp. 865-866 (doc. 502), sin las columnas de confirmantes.

CIT.- PAZ Y MÉLIA, A.: Ibidem; CORCHADO SORIANO, M.: Ibidem, p. 287: CAMPO REAL, F. del: Ibidem, pp. 26-27 y 669-670; RODRIGUEZ-PICAVEA MATILLA, E.: Ibidem, doc. 88, p. 66. 
«(Christus. Alfa. Omega). Tam presentibus quam futuris notum sit ac manifestum, quod ego ALDEFONSUS, DEI GRATIA REX Castelle et Toleti, una cum uxore mea Alienor, regina,/ uendo uobis dompno Nunio, calatraauensi magistro et fratribus uestris, castellum quod dicitur Malagon, pro quatuorcentis morabetinis, quod est situm in via qua itur de Toleto /ad Calatrauam et quod predicto precio supremoratum castellum preualet, offero, dono et concedo Deo et calatrauensi ordini, cum ingressibus et egressibus, pratis, /pascuis, riuis, aquis, molendinis, cum fontibus, montibus et nemoribus et cum omnibus directuris, terminis et pertinenciis suis, iure hereditario, uobis ha-/bendum et irreuocabiliter perpetuo possidendum. Si quis uero hanc cartam infringere uel diminuere presumpserit, iram Dei omnipotentis plenarie incurrat et insuper regie /parti mille aureos in coto persoluat et dampnum quod uobis intulerit dupplatum restituat.

Facta carta apud Toletum, era $\mathrm{M}^{\mathrm{a}} \mathrm{CC}^{\mathrm{a}} \mathrm{XXVI}, \mathrm{II}^{\mathrm{e}}$ nonas maii.

Et ego rex Aldefonsus, reg-/nans in Castella et Toleto, hanc cartam manu propria roboro et confirmo.

Gundissaluus, Toletane ecclesie archiepiscopus et Hyspaniarum primas, CONFIRMAT.

\section{(1 ${ }^{a}$ columna):}

Iohannes, Conchensis episcopus, confirmat.

Dominicus, Abulensis episcopus, confirmat.

Martinus, Segontinus episcopus, confirmat.

Martinus, Oxomensis episcopus, confirmat.

Comes Petrus, confirmat.

(Signo rodado: Cruz): SIGNUM / ALDEFONSI / REGIS / CASTELLE.

(Orlando a la rueda en semicírculo): Rodericus Guterrez, maiordomus curie regis, confirmat. Comes Ferrandus, alferiz regis, confirmat.

\section{( $2^{a}$ columna):}

Petrus Ferrandi, confirmat.

Rodericus Diaz, filius D. Xemeniz, confirmat.

Gomez Garsie, confirmat.

Ordonius Garsie, confirmat.

Lupus Diaz, merinus regis in Castella, confirmat.

\section{(Línea inferior)}

Magister Mica, regis notarius. Guterrio Roderici, existente cancellario, SCRIPSIT».

\section{(Al dorso):}

«De Malagón. Carta de Malagón. Priuilegio del rey don Alfonso que fizo donación a la orden e al maestre don... (Nuño)..., del castillo de Malagón por quatrocientos maravedis. Era M CC XX VI.

Este pruilegio e donación es uno de los que se traxeron del conuento de Calatraua por cédula de su Alteza, y se mandó entregar por los señores del Consejo de las Órdenes al señor Arias Pardo. Y en testimonio dello, yo Juan de Paredes, secretario del dicho Consejo, firmo aquí mi nombre. En Madrid, a XVIII de marzo, mil quinientos cincuenta y dos años. Johan de Paredes (rúbrica)». 


\section{AMBIENTACIÓN HISTÓRICA}

Por este documento, complementario del anterior, Alfonso VIII vende por 400 maravedís a la orden de Calatrava, a través de su maestre Nuño, todos los derechos que el propio monarca se había reservado ocho años atrás sobre la otra mitad del castillo y tierra de Malagón. Así, el 6 de mayo de 1188 la posesión calatrava del señorío y castillo de Malagón será ya completa a través de este nuevo privilegio rodado otorgado por el rey en Toledo, por el que hace entrega de Malagón a la orden tras el pago por ésta a la Corona de dicha cantidad.

Sin embargo, como consecuencia del desastre castellano en Alarcos (1195), el lugar retornó a poder musulmán hasta que fue recuperado por los cruzados cristianos los días 24 y 25 de junio de 1212, tras breve cerco, en la campaña que culminó al mes siguiente con la victoria de Alfonso VIII y sus aliados en Las Navas de Tolosa.

La guarnición musulmana que defendía el castillo de Malagón fue pasada a cuchillo por las fuerzas cristianas a pesar de que se había pactado la rendición. El arzobispo de Narbona, que acudió con aquellas huestes a la toma del lugar, describió la victoria sobre Malagón de los cruzados ultramontanos de esta forma: “... se apoderaron por fuerza de las cuatro torres laterales, y llegaron por ellas, minando hasta los cimientos, la torre principal, sin que por eso dejaran los moros de defenderse con el mayor esfuerzo posible desde lo alto de la torre, donde no podían subir todavía los nuestros libremente por las fuertes bóvedas que en medio había, hechas de ladrillo con cal y yeso; así que se trató concierto. Pedían los moros que se les dejara la vida, aunque con pérdida de la libertad, pero no quisieron los nuestros concedérselo y se entregó el castillo con calidad que prometieron la vida al alcaide y a dos hijos suyos, quedasen los demás al arbitrio de los peregrinos (cruzados), casi todos fueron pasados a cuchillo" [ cit. M. Corchado Soriano, El campo de Calatrava: los pueblos y sus términos (Guadalajara, 1982), p. 287, y J. GonzÁlez, El reino de Castilla..., I, 1016-1017 ].

Malagón y su tierra volvían a poder de la misma orden y permanecerían largo tiempo como encomienda calatrava, hasta que fueron desmembrados de la orden el 17 de noviembre de 1547, en paso efímero a tierra de realengo, para convertirse de inmediato en señorío perpetuo de los Arias Pardo. En efecto, el mariscal de Castilla y alcalde mayor de Sevilla Antonio Arias Pardo Tavera — también llamado Arias Pardo de Saavedra- ( ? -1561), tronco y principio de la Casa de los marqueses de Malagón, adquiría el 14 de enero de 1548 por compraventa al príncipe Felipe, en nombre de Carlos I, con un coste de 55.696.638 maravedís, la extinta encomienda calatrava de Malagón con todos sus términos, en señorío, y se posesionaba también de los lugares de Porzuna, Fuente el Fresno, Porzuna y demás anexos, aparte de Paracuellos de Jarama (A.D.M., Malagón, 1-21).

Estos pruilegios (3 y 4), junto con el resto de la documentación referida a Malagón que custodiaba la orden en su Archivo del convento de Calatraua, fueron entregados en 1552 por el secretario del Consejo de las Órdenes, Juan de Paredes, a Arias Pardo en virtud de real cédula de Carlos I.

Todos esos señoríos mencionados fueron incluidos en el mayorazgo que fundó el 9 de enero de 1561 el propio Arias Pardo, al tiempo de ordenar su testamento (A.D.M., Malagón, 6-11), un mayorazgo que su esposa, Luisa de la Cerda (hija del II Duque de Medinaceli), amplió más tarde incorporando la villa de Fernán Caballero, que ella había adquirido.

Arias Pardo fallecía en Toledo el 13 de enero de 1561, sucediéndole en el renovado mayorazgo de la Casa su primogénito, Juan Pardo Tavera (1550-1571), como segundo Señor de Malagón, Paracuellos y Fernán Caballero, y como Mariscal de Castilla. Pero con tan sólo 21 años, el 22 de octubre de 1571 moría sin descendencia el joven Juan, aún soltero. De esta 
manera, recayeron los estados en su hermana Guiomar Pardo Tavera ( ? -1622), aún en edad juvenil. Más tarde, el 16 de febrero de 1599 la señora de Malagón, junto con su esposo Juan Enríquez de Guzmán, recibían del recién entronizado monarca Felipe III la concesión conjunta - a él con nombre de Juan Pardo- del título de Marqueses de Malagón (A.D.M., Archivo Histórico, caja $2 \mathrm{n}^{\circ} 34-\mathrm{R}$ ), elevándose de esta forma a rango de marquesado el histórico dominio calatravo.

Sin embargo, Guiomar no tuvo descendencia y se extinguía con ella, en 1622, la línea de los Arias Pardo-Tavera. De ahí que, tras la resolución de una serie de pleitos en cuyo tiempo el marquesado de Malagón estuvo vacante, este estado y sus señoríos anexos de Fernán Caballero y Paracuellos de Jarama recayeron en el segundo Conde de Villalonso, Diego Ulloa Sarmiento III. Y aun cuando el heredero careció también de sucesión, lo cierto es que por vía de los condes de Villalonso - y, luego, de los también Condes del Castellar-, los dominios de la Casa de Malagón recalaron en la de Santisteban del Puerto en el primer cuarto del siglo XVIII. Y formando parte de las pertenencias de la Casa ducal de Santisteban del Puerto, pasarían a poder de los duques de Medinaceli en los inicios de la siguiente centuria. De ahí que estos privilegios rodados (los números 3 y 4) se localicen hoy formando parte del casi kilómetro lineal de documentos que se custodian en el Archivo Ducal de Medinaceli.

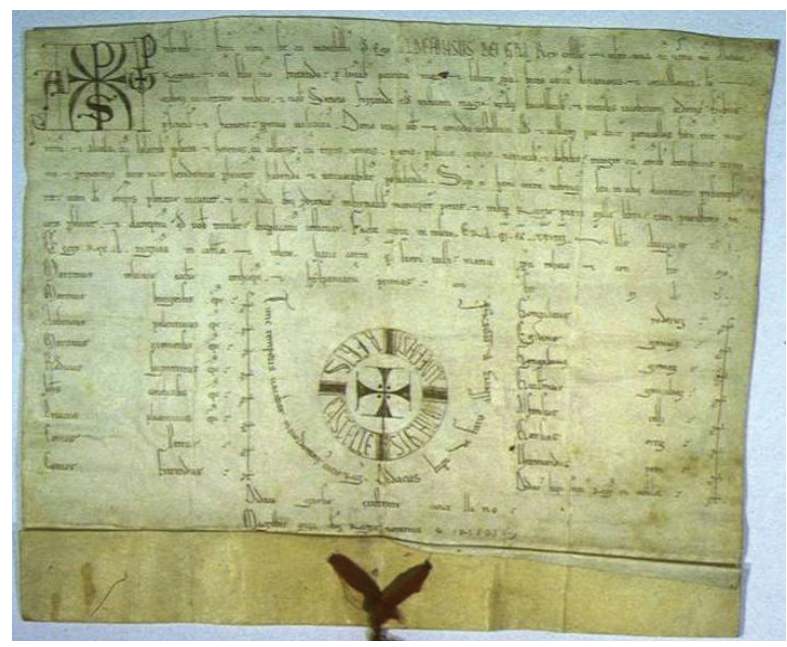

1195, julio, 28. Toledo.

Alfonso VIII, rey de Castilla, dona a la orden de Santiago y a su maestre, Sancho Fernández, la villa y castillo de "Paracollos" (Paracuellos de Jarama), entre Madrid y Alcalá.

A.- ADM, Privilegios Rodados, n $^{\circ} 5$ (Procedencia: A.D.M., Paracuellos, 1-2). Pergamino 455 x $365+55 \mathrm{~mm}$. Buen estado de conservación. Crismón y rueda de tinta. Texto en latín. Tinta ocre. Escritura carolina pregótica. Conserva el sello de plomo pendiente de hilos de seda granates y amarillos.

B.- AHN, Uclés, caja 260, nº 17, fol. 7. - Traslado del siglo XVIII.

C.- AHN, Tumbo Menor de Castilla, lib. I, escr. 5, fols. 22-23. 
EDIT.: GONZÁLEZ, J.: El reino de Castilla en la época de Alfonso VIII, tomo III, pp. 146-147 (doc. 646).

CIT.- SALAZAR Y CASTRO, L.: Historia de la Casa de Lara, 2 vols. (Madrid, 1697) tomo I, p. 152; CHAVES, B. de: Apuntamiento legal sobre el dominio solar que por expresas reales donaciones pertenece a la Orden de Santiago en todos sus pueblos (Madrid, 1740), fol. 14 vto.; PAZ Y MÉLIA, A.: Series... I, p. 439; SERRANO, L.: El obispado de Burgos y Castilla primitiva desde el siglo V al XIII. 3 vols. (Madrid, 1935), tomo II, p. 144; GARCÍA DEL ARROYO, C.: Privilegios reales de la orden de Santiago, p. 105 (doc. 162).

«(Christus. Alfa. Omega). Presentibus et futuris notum sit ac manifestum, quod ego AldEfonsus, Dei gratia ReX Castelle et Toleti, una cum uxore mea Alienor $/ 2$ Regina, et cum filio meo Ferrando, pro animabus parentum meorum et salute propia, facio cartam donationis et concessionis Deo et / ordini Iacobitane milicie, et uobis Sancio Ferrandi, eiusdem instante magistrum, uestrisque successoribus et uniuersis Iacobitani ordinis fratribus $/{ }^{4}$ presentibus et futuris, perpetuo ualituram. Dono itaque uobis et concedum castellum illud et uillam que dicitur Paracollos, sitam inter Maie-/ritum et Alcala, cum solaribus populatis et heremis, cum collaciis, cum terris, uineis, pratis, pascuis, aquis, nemoribus et defesis, integre, cum ómnibus directuris, termi- $/{ }^{6}$ nis et pertinentiis suis, iure hereditario perhenniter habendam et irreuocabiliter possidendam.

$\mathrm{Si}$ quis uero hanc cartam infringere seu in aliquo diminuere presumpse-/rit, iram Dei omnipotentis plenarie incurrat et cum Iuda, Domini proditore infernalibus mancipetur penis, et insuper regie parti mille libras auri purissimi in $/ 8$ coto persoluat et dampnum quod uobis intulerit dupplatum restituat.

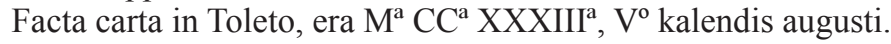

Et ego rex Aldefonsus, regnans in Castella et Toleto, hanc cartam, quam fieri iussi, manu propria roboro et confirmo.

Martinus, Toletane ecclesie archiepiscopus et Hyspaniarum primas, confirmat.

\section{(1 ${ }^{a}$ columna):}

Marinus, Burgensis episcopus, confirmat.

Ardericus, Palentinus episcopus, confirmat.

Martinus, Oxomensis episcopus, confirmat.

Rodericus, Segontinus episcopus, confirmat.

Iohannes, Conchensis episcopus, confirmat.

Briccius, Placentinus episcopus, confirmat.

Comes Petrus, confirmat.

Comes Ferrandus, confirmat.

(Signo rodado: Cruz -ocupando ya casi todo el campo-): SIGNUM / ALDEFONSI / REGIS / CASTELLE.

(Orlando a la rueda en semicírculo): Tunc temporis uacabat maiordomatus curie regis ${ }^{108}$.

Didacus Lupi de Faro, alferiz regis, confirmat.

\section{( $2^{a}$ columna):}

Gonzaluus Roderici, confirmat.

108 Poco después era nombrado Pedro García de Lerma, por segunda vez, para cubrir esta vacante de mayordomo real. Cfr. J. DE SAlAzAR y Acha, La casa del rey de Castilla y León en la Edad Media (Madrid, 2000), p. 374. 
Egidius Gomez, confirmat.

Gonzaluus Gomez, confirmat.

Guillemus Gonzaluez, confirmat.

Alfonsus Telli, confirmat.

Garsias Ortiz, confirmat.

Uermundus Petri, confirmat.

Didacus Lupi, merinus regis in Castella, confirmat.

\section{(Línea inferior)}

Didaco Garsie, existente cancellario.

Magister Mica, domini regis notarius, SCRIPSIT ».

\section{AMBIENTACIÓN HISTÓRICA}

Por este privilegio rodado, complementario del primero de esta colección antes comentado, veinte años después de aquella concesión de Paracuellos de Jarama al caballero Fernando Martínez de Hita, el 28 de julio de 1195, el propio rey Alfonso VIII otorgaba en Toledo este otro privilegio rodado por el que hacía nueva donación de la villa y su castillo a la orden de Santiago en la persona de su maestre, Sancho Fernández.

Posteriormente en Palencia, el 18 de mayo de 1217 el maestre santiaguista García González de Arauzo y el convento de Uclés dan la posesión vitalicia de Paracuellos al conde Alvar Núnez de Lara, procurador del rey-niño Enrique I, y a su mujer Urraca, junto con el castillo de Malsobaco, situado al suroeste del término. Más tarde, en 1243, Gil Gómez do Vinhal renuncia a sus cuatro castillos de Murcia en favor de la orden de Santiago a cambio de la encomienda de Paracuellos ( “... Gil Gomes comendador de Paracuellos...”, dice el documento: AHN, Ordenes Militares - Uclés, leg. 328, núm.13). E incluso más tarde, en la primera mitad del siglo XV, parece que pasa a ser gobernada por los señores de Ayala.

En 1531, el príncipe Felipe - estando su padre, el emperador Carlos V, en Alemania y en nombre suyo - vendió la villa de Paracuellos de Jarama al mariscal de Castilla Arias Pardo de Saavedra, el mismo que años después adquiría también la encomienda calatraveña de Malagón.

Y juntas las extintas encomiendas santiaguista (en el caso de Paracuellos) y calatraveña (en el de Malagón) tendrían una evolución pareja en adelante - que ya conocemos-, hasta incorporarse en el siglo XIX a los dominios de la Casa Ducal de Medinaceli a través de las de Malagón, Villalonso y Santisteban del Puerto. 
$-6-$

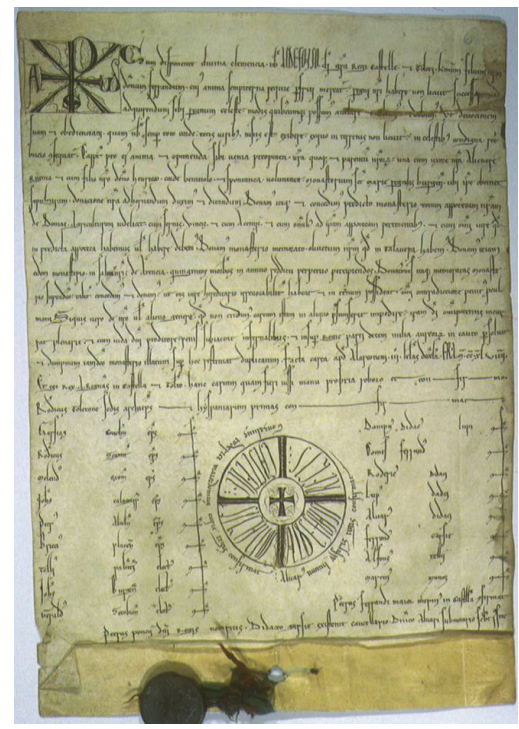

1211, noviembre, 29. Alarcón.

Alfonso VIII, rey de Castilla, dona a la comunidad de las Huelgas de Burgos, en cuyo monasterio acaba de ser sepultado el infante don Fernando, la bodega regia de Donias (Dueñas), un olivar en Talavera y 500 maravedis anuales de renta situada sobre las salinas de Atienza.

\section{(VERSIÓN A)}

A.- ADM, Privilegios Rodados, $\mathrm{n}^{\circ} 6$ (Procedencia: A.D.M., secc. Adelantamiento de Castilla). Pergamino 340 x 490 +50 mm. Buen estado de conservación. Crismón y rueda de tinta, sin iluminar. Texto en latín. Escritura carolina pregótica. Tinta negra. Conserva el sello de plomo, pendiente de hilos rojos y verdes (aunque es necesario fijarlo convenientemente).

* Entre los confirmantes aparece "Martín Muñoz (de Finojosa)".

B.- RAH, colecc. Velázquez, $\mathrm{n}^{\mathrm{o}} 1$.

CIT.- PAZ Y MÉLIA, A.: Series... I, p. 439.

\section{(VERSIÓN B)}

A.- AMHB, leg. 4, nº 117-B.

B.- AMHB, leg. $1, n^{\circ} 8-A$. Copia de la época.

C.- AMHB, leg. $6, \mathrm{n}^{\circ}$ 203. Copia también coetánea.

D.- ADM, Privilegios Rodados, $\mathrm{n}^{\mathrm{o}} 7$. Doc. inserto.

E.- RAH, colecc. Salazar, O-17, fols. 619-620. Copia de principios del siglo XVII.

F.- BCC, manuscrito 85-5-11 (s.f.) Copia del siglo XVII.

G.- BN, manuscrito 720, fols. 170-171. Copia también del siglo XVII.

H.- RAH, colecc. Salazar, O-23, fol. 78. Copia del mismo siglo XVII.

I.- RAH, Ibidem, O-22, fol. 126 vto. Copia del siglo XVII. 
J.- AMS, manuscrito 6, fol. 177. Copia incompleta del siglo XVIII.

K.- AMS, manuscrito 7, fols. 130 vto.-131 vto. Copia del siglo XVIII.

L.- RAH, colecc. Abella, 94 - sin foliar-. Copia del mismo siglo XVIII.

M.- RAH, Ibidem. Copia parcial del siglo XVIII.

EDIT.- RODRÍGUEZ LÓPEZ, A.: El Real Monasterio de Las Huelgas de Burgos (Apuntes para su historia y Colección diplomática), 2 vols. (Burgos 1907), I, pp. 349-350; GONZÁLEZ, J.: Ibidem, III, pp. 554-556 (doc. 888); LIZOAIN GARRIDO, J.M.: Documentación del Monasterio de las Huelgas de Burgos (1116-1230), doc. 109, pp. 174-176.

CIT.- RODRÍGUEZ, Amancio: Historia del monasterio de las Huelgas (Burgos, 1916), tomo II, p. 349.

«(Christus. Alfa. Omega). Cum disponente diuina clementia, nobis Aldefonso, Dei gratia regi Castelle et Toleti, karissimum filium nostrum /dompnum Ferrandum, cuius anima sempiterna requie perfrui mereatur, regni nostri habere non licuit successorem, ad /3adquirendum sibi regnum celeste, modis quibuscumque possumus anelare, et debemus et uolumus, ut deuocionem /suam et obedienciam, quam nobis semper toto corde, totis uiribus, nisus est exhibere, ex quo in terrenis non licuit in celestibus condigna retri-/bucio consequator. Ea propter, pro eius anima et optinenda sibi uenia, preoptata nostra quoque et parentum nostrorum, una cum uxore nostra Alienore $/{ }^{6}$ Regina, et cum filio nostro dompno Henrico, corde beniuolo et spontanea uoluntate, monasterium sancte Marie Regalis burgensis, ubi ipse obtinet /sepulturam, donacione nostra ad hornamdum duximus et ditandum. Donamus itaque et concedimus predicto monasterio totam appotecam nostram /de Donias, agriculturam uidelicet, cum sernis, uineis et cum aceniis, et cum omnibus ad ipsam appotecam pertinentibus, et cum omni iure quod $/{ }^{9}$ in predicta appoteca habemus uel habere debemus. Donamus monasterio memorato oliuetum nostrum quod in Talauera habemus. Donamus etiam /eidem monasterio, in salinis nostris de Atencia, quingentos morabetinos in annuo redditu perpetuo percipiendos ${ }^{109}$. Donationes itaque memoratas monaste-/rio supradicto taliter concedimus et donamus, ut eas iure hereditario irreuocabiliter habeat et in eternum possideat, omni contradiccione pernitus procul $/{ }^{12}$ mota.

Si quis uero de nostro uel de alio genere, quod non credimus, cartam istam in aliquo presumpserit impedire, iram Dei omnipotentis incur-/rat plenarie, et cum Iuda, Domini proditore, penis subiaceat infernabilus, et insuper regie parti decem milia aureorum in cauto persoluat, / et dampnum iam dicto monasterio illatum super hoc restituat duplicatum.

Facta carta apud Alarconem, III' kalendas decembris, ERA $\mathrm{M}^{\mathrm{a}} \mathrm{CC}^{\mathrm{a}} \mathrm{XL}^{\mathrm{a}} \mathrm{VIIII}^{\mathrm{a}}$.

$/{ }^{15}$ Et ego, rex Aldefonsus, regnans in Castella et Toleto, hanc cartam, quam fieri iussi, manu propria roboro et confirmo.

/Rodericus, Toletane sedis archiepiscopus et Hyspaniarum primas, confirmat.

\section{(1 ${ }^{a}$ columna):}

Garsias, Conchensis episcopus, confirmat.

Rodericus, Segontinus episcopus, confirmat.

Melendus, Oxomensis episcopus, confirmat.

Iohannes, Calagurritanus episcopus, confirmat.

109 En el privilegio que se conserva en el Archivo burgalés de Las Huelgas (versión B) prosigue el dispositivo aclarando esta donación económica en rentas sobre las salinas de Atienza: “...per festum Sancti Iohannis Baptiste, omnes in simul quolibet anno, ideo enim in tantum terminum persoluenti predictos aureos protelamus, ut omnes in simul tribuantur ad terminum prelibatum, eo quod intelligamus maius monasterii comodum contineri percipiendo eos omnes in simul dicta die. Mandamus itaque ei quicumque salinas tenuerit ut predictos quingentos aureos per festum Sancti Iohannis omnes in simul det quolibet anno in perpetuum monasterio memorato". 
Petrus, Abulensis episcopus, confirmat.

Briccius, Placentinus episcopus, confirmat.

Tellius, Palentinus episcopus, confirmat.

Iohannes, Burgensis episcopus, confirmat.

Giraldus, Secobiensis episcopus, confirmat.

(Signo rodado: Cruz - de nuevo achicada y por primera vez decorada, ensanchándose en cambio el anillo de la leyenda-): SIGNUM / ALDEFONSI / REGIS / CASTELLE.

(Orlando a la rueda en semicírculo): Gonzaluus Roderici, maiordomus curie regis, confirmat : Aluarus Nunii, alferiz regis, confirmat.

(2a columna):

Dompnus Didacus Lupi, confirmat.

Comes Ferrandus, confirmat.

Rodericus Didaci, confirmat.

Lupus Didaci, confirmat.

Aluarus Didaci, confirmat.

Ferrandus Garsie, confirmat.

Alfonsus Tellii, confirmat.

Martinus Munioz, confirmat.

Petrus Ferrandi, maior merinus in Castella, confirmat.

\section{(Línea inferior)}

Petrus Poncii, domini regis notarius. Didaco Garsie, existente cancellario. Dominico Aluari, subnotario, scribere iussit».

$* * *$

\section{AMBIENTACIÓN HISTÓRICA}

Por este privilegio rodado - en su doble versión- Alfonso VIII dona al monasterio de las Huelgas de Burgos, que él mismo había fundado como enterramiento de la casa real, una serie de propiedades para sostenimiento de la comunidad: concretamente la bodega regia de Donias (Dueñas), un olivar en Talavera y 500 maravedís anuales de renta situada sobre las salinas de Atienza. Apenas mes y medio antes, la noche del 14 de octubre de 1211 en Madrid, había fallecido inesperadamente el infante heredero don Fernando y después había sido sepultado en el monasterio real burgalés, lo que venía a justificar esta donación del monarca a la comunidad religiosa.

Este infante había nacido el 29 de noviembre de 1189 y en él habían puesto sus padres todas sus esperanzas sucesorias, y Castilla entera sus ilusiones; de ahí que fuera educado para rey desde la más tierna edad; de hecho, muy pronto comenzaron a hacerle partícipe de la gobernabilidad del reino y de la dirección de la guerra. Pero a los 22 años le sorprendió la muerte cuando regresaba de una campaña que había dirigido contra Montánchez y Trujillo para aflojar el cerco que los almohades sometían al castillo de Salvatierra. El dolor de los monarcas y de todo el reino fue inmenso por esta pérdida. Le sucedía entonces como heredero del trono castellano su hermano Enrique, que tenía 7 años y medio en ese momento y que, sólo tres años después, sería el nuevo rey castellano con nombre de Enrique I. 